NBER WORKING PAPER SERIES

\title{
THE EFFECT OF PRINCIPAL REDUCTION ON HOUSEHOLD DISTRESS: EVIDENCE FROM MORTGAGE CRAMDOWN
}

\author{
Jacelly C. Cespedes \\ Carlos R. Parra \\ Clemens Sialm \\ Working Paper 28900 \\ http://www.nber.org/papers/w28900 \\ NATIONAL BUREAU OF ECONOMIC RESEARCH \\ 1050 Massachusetts Avenue \\ Cambridge, MA 02138 \\ June 2021
}

We are grateful to Hengjie Ai, Vimal Balasubramaniam, Ed Boltz, Peter Ganong, Borja Larrain, Feng Liu, Gonzalo Maturana, Felipe Severino, Jose Tessada, Tracy Wang, and seminar participants at the 2020 Virtual Real Estate Seminar, the 2021 CEPR European Workshop on Household Finance, the 2021 Consumer Financial Protection Bureau Research Conference, the 2021 University of Connecticut Finance Conference, the Pontificia Universitad Catolica de Chile, the Universidad Adolfo Ibanez, the University of Minnesota, and the University of Texas at Austin. In addition, we thank Tal Gross, Matthew Notowidigdo, and Jialan Wang for sharing their PACER dockets data and Joshua Goodman and Adam Levitin for sharing their data on the cramdown court rulings. Clemens Sialm is an independent contractor with AQR Capital Management. This research received generous financial support from the Alfred P. Sloan Foundation NBER Household Finance small grant program. The views expressed herein are those of the authors and do not necessarily reflect the views of the National Bureau of Economic Research.

At least one co-author has disclosed additional relationships of potential relevance for this research. Further information is available online at http://www.nber.org/papers/w28900.ack

NBER working papers are circulated for discussion and comment purposes. They have not been peer-reviewed or been subject to the review by the NBER Board of Directors that accompanies official NBER publications.

(C) 2021 by Jacelly C. Cespedes, Carlos R. Parra, and Clemens Sialm. All rights reserved. Short sections of text, not to exceed two paragraphs, may be quoted without explicit permission provided that full credit, including ( $)$ notice, is given to the source. 
The Effect of Principal Reduction on Household Distress: Evidence from Mortgage Cramdown Jacelly C. Cespedes, Carlos R. Parra, and Clemens Sialm

NBER Working Paper No. 28900

June 2021

JEL No. G21,G28,G41,G51,H31,H73,K25,K35

\section{ABSTRACT}

Mortgage cramdown enabled bankruptcy judges to discharge the underwater portion of a mortgage during Chapter 13 bankruptcy before the Supreme Court disallowed this practice in 1993. We exploit the random assignment of cases to judges to quantify the ex-post effects of Chapter 13 bankruptcy over the period from 1989 to 1993 . We find that a successful Chapter 13 filing in a cramdown court substantially decreases the five-year foreclosure rate, the propensity to move, and the crime rate. Our results suggest that principal write-down considerably reduces homeowner's distress.

Jacelly C. Cespedes

University of Minnesota

321 19th Avenue South, 3-135

Minneapolis, Mn 55455

United States

cespe013@umn.edu

Carlos R. Parra

PUC Chile

Avenida Vicuna Mackenna 4860

Macul 7820436

Chile

parra.c.carlos.r@gmail.com
Clemens Sialm

University of Texas at Austin

McCombs School of Business

2110 Speedway; B6600

Austin, TX 78712-1276

and NBER

clemens.sialm@mccombs.utexas.edu 


\section{Introduction}

The United States experienced an unprecedented number of home foreclosures during the Great Recession of 2007-2009. To limit defaults and deadweight losses, the government implemented various policies that reduced monthly payments (i.e., Home Affordable Modification Program (HAMP)) and facilitated mortgage refinancing (i.e., Home Affordable Refinancing Program (HARP)). However, various frictions in intermediation brought about only modest success for these initiatives. ${ }^{1}$ An alternative policy proposal that was not implemented during the Great Recession would have allowed mortgage cramdown by judges as part of the Chapter 13 bankruptcy process. In these restructurings, the underwater portion of the mortgage is treated as unsecured debt and can be discharged during bankruptcy. Our paper investigates this alternative policy by estimating the effects of bankruptcy discharge on borrowers who benefit from mortgage cramdown.

Chapter 13 bankruptcy allows debtors to restructure almost all types of debt, except for loans on the principal place of residence. ${ }^{2}$ However, some bankruptcy courts had been discharging the underwater portion of the mortgage during bankruptcy until the Supreme Court disallowed this practice in 1993. Although borrowers have to maintain the obligation to meet their monthly mortgage payments following the original terms of the loans, cramdown is beneficial for underwater borrowers because it reduces the debt owed on the property. Cramdown thereby diminishes the incentives for homeowners to default on their properties and decreases the likelihood of households being forced to move from their homes.

In this paper, we estimate the effect of mortgage cramdown on foreclosure and other economic outcomes. To this end, we estimate the causal effect of the bankruptcy

\footnotetext{
${ }^{1}$ Agarwal et al. (2015) and Agarwal et al. (2017) show that securitization, which made renegotiations difficult, and servicers' organizational capacity hampered the impact of these policies.

${ }^{2}$ Other debts that cannot be discharged in bankruptcy are domestic support obligations, criminal penalties, penalties owed to government agencies, taxes, student loans, and fraudulent debts.
} 
discharge using the judge's leniency as an instrumental variable for bankruptcy protection, similar to Dobbie and Song (2015) and Dobbie, Goldsmith-Pinkham, and Yang (2017). ${ }^{3}$ As indicated by Sullivan, Warren, and Westbrook (1994), Norberg and Compo (2007), and Chang and Schoar (2013), the variation in leniency across judges is substantial. The main identifying assumptions are that judge assignments are associated with bankruptcy protection and that these assignments only impact debtor outcomes through the probabilities of receiving bankruptcy protection.

We also investigate whether the discharge decisions and the subsequent borrower outcomes depend on the characteristics of the filers for bankruptcy protection. In particular, we study whether judges impose differential thresholds on female filers and whether the benefits of bankruptcy protection differ by gender. ${ }^{4}$

To estimate the impact of cramdown in Chapter 13 bankruptcy on debtor's home foreclosures and other economic outcomes, we compile a new data set. First, we collect information from the Public Access to Court Electronic Records (PACER) system, and we complement our data with bankruptcy information from Gross, Notowidigdo, and Wang (2014). Second, we match this data set with two other data sources to study debtors' mortgage defaults and other post-filing outcomes. Our sample contains bankruptcy records from 14,517 cases: 6,100 in cramdown courts and 8,417 in noncramdown courts. To obtain information about the courts that allowed cramdown, we merge our data set with data collected by Goodman and Levitin (2014).

Our main result shows that a bankruptcy discharge in Chapter 13 in a cramdown court has a large impact on future mortgage distress. We find that a discharge in a cramdown court reduces the five-year foreclosure rate by 29 percentage points and in-

\footnotetext{
${ }^{3} \mathrm{~A}$ similar empirical strategy has been used to estimate the ex-post impact of the sentence length on earnings (Kling, 2006), foster care effects (Doyle, 2007), juvenile incarceration (Aizer and Doyle Jr, 2015), and corporate bankruptcy (Chang and Schoar, 2013).

${ }^{4}$ There is a large literature studying the gender gap in consumer financial decisions and a smaller literature on the gender gap in personal bankruptcy. Driscoll (1994) concludes that the "bankruptcy system does not appear to operate in a manner that overtly or intentionally discriminates against women." Agarwal, He, Sing, and Zhang (2018) argue that the gender gap in bankruptcy risk in Singapore is mainly driven by risk-taking behavior.
} 
voluntary sales (i.e., property sales for less than the mortgage amount) by 26 percentage points. We also find that discharge in cramdown courts stabilizes living arrangements and circumstances of households. Households are less likely to move overall, and when they do, they are more likely to move to neighborhoods with higher income levels. Furthermore, households whose debt is discharged in cramdown courts experience a significant reduction in subsequent criminal filings.

We find beneficial effects of discharge in cramdown courts across different demographic groups. However, the benefits are more pronounced for female filers. For example, involuntary sales decline by 41 percentage points for female and by only 22 percentage points for male filers. These economically large differences may occur because judges might require a higher threshold for female filers to qualify for Chapter 13 debt discharge. Indeed, the discharge rate for female filers is 4 to 5 percentage points lower than for male filers after controlling for other filer characteristics and court fixed effects. The differential treatment of female filers by judges may be due to systematic patterns of "in-group" tolerance, as discussed by Egan, Matvos, and Seru (2018) in the context of misconduct in the financial advisory industry.

It remains unclear whether the beneficial discharge effects are driven by the cramdown provisions or by other features of debt restructuring through Chapter 13. To address this question, we combine our samples from cramdown and non-cramdown courts and study whether the effects differ across the two samples. We find that the five-year foreclosure rate declines by 29 percentage points in cramdown courts and by 5 percentage points in non-cramdown courts. Thus, our results indicate that the cramdown provision is the main driver of the beneficial effects of bankruptcy discharge in cramdown courts. Therefore, given the substantial costs of foreclosure, cramdown has significant benefits for homeowners (Diamond, Gureny, and Tan, 2020).

We also provide a partial-equilibrium back-of-the-envelope calculation of how many foreclosures could have been avoided had the United States allowed mortgage cram- 
down during the 2008-2013 period. Our estimates indicate that more than half a million foreclosures could have been avoided with mortgage cramdown. This estimate supports the hypothesis that cramdown would have been an effective policy tool to reduce foreclosures. ${ }^{5}$ However, these benefits can potentially be partially offset by higher costs imposed on borrowers who do not declare bankruptcy and mortgage lenders.

Our paper builds on an important literature in household finance that studies the impact of bankruptcy on foreclosures and other economic outcomes. Our paper is most related to Dobbie and Song (2015), who use random judge assignments to study the impact of unsecured debt relief from Chapter 13 protection on subsequent earnings, foreclosures, and mortality over the period from 1992 to 2005. They document significant economic benefits for households with successful bankruptcy filings. Furthermore, Dobbie, Goldsmith-Pinkham, and Yang (2017) also study the effect of Chapter 13 bankruptcy protection on financial health. Our paper studies the benefits of principal reductions (secured debt relief) over the period from 1989 to 1993 . We are the first to provide estimates of the ex-post impact of mortgage cramdown from Chapter 13 on mortgage default and other outcomes using a newly compiled data set. Whereas Dobbie and Song (2015) estimate a large effect of unsecured debt relief through Chapter 13 on avoiding foreclosure, we show that the effect of Chapter 13 in cramdown courts is substantially larger relative to the standard Chapter 13 protection.

By estimating the ex-post effect of principal reduction, our paper also contributes to the literature on cramdown. White and Zhu (2010) examine how filing for bankruptcy helps financially distressed homeowners and present a model that evaluates the effects of introducing a cramdown provision after the 2005 bankruptcy reform. Goodman and Levitin (2014) analyze whether cramdown affects the cost of credit in the mortgage market, whereas Li, Tewari, and White (2014) estimate the effect of cramdown on the

\footnotetext{
${ }^{5}$ Luzzetti and Neumuller (2014), Agarwal et al. (2015), Agarwal et al. (2017), Abel and Fuster (2018), Ganong and Noel (2018), Piskorski and Seru (2018a), Piskorski and Seru (2018b), Gross et al. (2019), and Kaplan, Mitman, and Violante (2020) also study the impact of alternative policies on the financial crisis.
} 
supply of mortgages. Interestingly, both of these papers find small effects on the supply side. Goodman and Levitin (2014) find that home loans closed during the time when cramdown was allowed had interest rates 12-16 basis points higher than loans closed in the same state when cramdown was not allowed, which translates to a roughly $1 \%$ increase in the monthly payments. Similarly, Li, Tewari, and White (2014) find that the Supreme Court decision led to a short-term reduction of 3\% in mortgage interest rates and a short-term increase of $1 \%$ in mortgage approval rates, but only the approval rate effect persists in longer sample periods.

A growing literature studies the mechanisms that explain household default and the effect of various debt-relief interventions. Regarding the drivers of default, there is a longstanding debate on whether mortgage default is triggered by adverse life events (Riddiough, 1991), negative equity (Foster and Van Order, 1984), or both (Foote, Gerardi, and Willen, 2008). Concerning interventions, Ganong and Noel (2018) document that maturity extensions that increase liquidity have substantial benefits on debtors, while (small) principal reductions have no effect. Dobbie and Song (2020) find that interest write-downs provide positive benefits, whereas immediate payment reductions do not help debtors. Ganong and Noel (2020) find that negative equity exclusively causes a small fraction of defaults. We contribute to this literature by estimating the effect of large principal reductions on mortgage loans and documenting substantial effects, even in the short term, on debtors for this type of intervention. In addition, relative to other papers that study unsecured debt-relief interventions, our setting allows us to examine the mortgage debt overhang motive for defaulting. ${ }^{6}$

The remainder of our paper is structured as follows: We discuss the institutional background and the differences between Chapters 7 and 13 bankruptcy in Section 2 . Section 3 describes the data sources and summary statistics. Section 4 presents the

\footnotetext{
${ }^{6}$ Elul et al. (2010), Guiso, Sapienza, and Zingales (2013), Mayer, Morrison, Piskorski, and Gupta (2014), Bhutta, Dokko, and Shan (2017), Gerardi, Herkenhoff, Ohanian, and Willen (2018), Abel and Fuster (2018), and Gupta and Hansman (2020) also study the determinants of mortgage default and evaluate debt-relief interventions.
} 
research design. Section 5 presents our main results, and Section 6 compares outcomes of bankruptcy filings in cramdown with non-cramdown courts. Section 7 discusses our results and Section 8 concludes.

\section{Institutional Background}

The United States has two personal bankruptcy provisions: Chapter 7 and Chapter 13. Chapter 7 provides unsecured debt relief and protection from wage garnishment in exchange for a debtor's non-exempt assets. In contrast, Chapter 13 bankruptcy filers must forgo part of their future earnings to repay creditors. Therefore, debtors seeking to retain their assets are more likely to file for Chapter 13. Overall, both bankruptcy provisions allow total or partial forgiveness of unsecured obligations, such as credit card debt, unpaid rent, and medical bills.

Based on the 1978 Bankruptcy code, which was amended in 1984, Chapter 13 debtors are required to use all their disposable income to propose a three-year repayment plan (White, 1987). ${ }^{7}$ The main restriction is that the total proposed repayment cannot be less than the value of a debtor's non-exempt assets under Chapter 7. Filers need to submit a bankruptcy petition, a repayment plan, a summary of financial affairs, a copy of tax returns, and the standardized forms of income, expenditures, and assets and liabilities. Subsequently, within each bankruptcy office, filers are typically assigned to judges using a blind rotation system. The debtor meets with a bankruptcy trustee who reviews the claims by creditors and debtors, challenges any aspects of the bankruptcy case if needed, and collects the bankruptcy proceeds during the repayment plan. Finally, the filer appears before the bankruptcy judge at the plan confirmation hearing. This is the only time when the judge and the filer meet. The main role of the assigned judge is to decide all matters connected to a case, in particular, whether or not to dismiss the filing.

\footnotetext{
${ }^{7}$ After the 2005 Bankruptcy Reform, the repayment plans last between three and five years.
} 
Chapter 13 allows debtors to restructure almost all types of debt, except home mortgage loans. In particular, Section 1322(b)(2) of the Bankruptcy Code provides that a Chapter 13 repayment plan may "modify the rights of holders of secured claims, other than a claim secured only by a security interest in real property that is the debtor's principal residence" (11 U.S.C. §1322(b)(2)). Therefore, any mortgage arrears, late fees, and regular installments should be paid off according to their original terms; otherwise, the mortgagee has the right to foreclose on the property (Goodman and Levitin, 2014). The rationale behind restricting mortgage cramdown for a principal residence is to encourage the flow of capital into the home lending market (Levitin, 2009).

Although mortgage modification is typically prohibited in Chapter 13 bankruptcy, some bankruptcy courts allowed principal mortgage reduction, a practice known as mortgage cramdown, between 1981 and June 1993. These decisions were not built on policy analysis; instead, they were based on statutory interpretations (Levitin, 2009). In particular, these courts understood cramdown as a simple reclassification of the loan in bankruptcy. The main argument was that the prohibitive clause (the "other than") of $\S 1322(\mathrm{~b})(2)$ was limited to the value of the collateral, whereas any negative equity could be classified as unsecured debt and, thus, was dischargeable through bankruptcy. ${ }^{8}$ Thus, the mortgage loans were "bifurcated" into a secured component, corresponding to the value of the property, and an unsecured component, corresponding to the underwater portion of the loan, that could be discharged. ${ }^{9}$

${ }^{8}$ Mullaugh (1994) states that the courts that approved the cramdown under Chapter 13 plans based their decisions on four factors: "First, and perhaps most importantly, the courts felt that the plain language of the statutory provisions commanded the conclusion that bifurcation was permissible in the case of undersecured home mortgages. Second, the long-settled rules of statutory construction led to the same result as the plain language. Third, the legislative history, though sparse, evinced a Congressional intent to balance the interests of the debtor and the home mortgage lender through a compromise between the House and the Senate drafts of the relevant statutory provisions. Lastly, the policy underlying the bankruptcy framework, especially the policies underlying Chapter 13 reorganization, favored allowing the debtor to 'strip down' an undersecured home mortgage to better achieve the bankruptcy goal of a 'fresh start' for debtors."

${ }^{9} 11$ U.S.C. $\$ 506(a)$ reads, in pertinent part: "An allowed claim of a creditor secured by a lien on property in which the estate has an interest [..] is a secured claim to the extent of the value of such creditor's interest [..] and is an unsecured claim to the extent that the value of such creditor's interest $[.$.$] is less than the amount of such allowed claim."$ 
In practice, a Chapter 13 filer had to propose a repayment plan with the remaining secured claim. Under this plan, the filer had to pay the arrearages in full within a reasonable time and continue to make the monthly payments following the original terms of the loan until the principal had been paid in an amount equal to the value of the property. In courts that allowed cramdown, any negative equity portion of the mortgage was automatically forgiven if the Chapter 13 filing was discharged. ${ }^{10}$

In June 1993, the Supreme Court prohibited cramdown after ruling on the issue in Nobelman v. American Savings Bank (508 U.S. 324 [1993]), a decision that banned cramdown in all states. The Supreme Court's rationale was to provide special protection to home mortgage lenders to enable them to offer lower interest rates and thus promote homeownership. ${ }^{11}$

Prior to the Supreme Court's decision on Nobelman v. American Savings Bank in 1993, four different circuit courts had allowed the practice of cramdown (i.e., the 2nd, 3rd, 9th, and 10th). ${ }^{12}$ However, the 5th circuit court did not approve the practice after hearing the Nobelman case in August 1992. Prior to Nobelman, no circuit court had explicitly barred cramdown in Chapter 13, and several bankruptcy courts in other circuits had approved Chapter 13 reorganization plans that included cramdowns of undersecured home mortgages (Mullaugh, 1994). It is important to note that a judge's decision in a bankruptcy case might change law. However, any decision affects only the jurisdiction (district) in which the judge is presiding, a fact that generates differences in law across districts within a circuit court (Li, Tewari, and White, 2014). In particular, between 1981 and 1993, 38 courts in 29 states allowed mortgage principal reduction; 32 of them permitted cramdown after 1988.

\footnotetext{
${ }^{10}$ An example is the Wilsons' bankruptcy filing. In 1983, the Wilsons purchased their home. By 1988 , the balance of the mortgage was $\$ 38,176.75$, while the market value of the Wilson's home had depreciated to $\$ 22,000$. Wilsons' Chapter 13 plan bifurcated the mortgage debt under section 506(a), thus limiting the secured claim to $\$ 22,000$ (Wilson v. Commonwealth Mortgage Corp., 895 F.2d 123, 128 (3d Cir. 1990)).

${ }^{11}$ Nobelman v. American Savings Bank, 508 U.S. 324 (1993).

${ }^{12}$ There are 11 circuit courts in the United States, and each circuit court covers two to nine states. Each state is divided into one to four bankruptcy court regions.
} 


\section{Data Sources and Summary Statistics}

To estimate the impact of cramdown in Chapter 13 bankruptcy on debtors' home foreclosures and other outcomes, we assemble several data sets obtained from different sources.

\subsection{Data Sources}

We compile a new data set from the PACER system. We received fee exemptions to the docket records of 59 bankruptcy district courts in 36 states. In addition, we complement our data with bankruptcy data from Gross, Notowidigdo, and Wang (2014). Thus, our sample contains bankruptcy records from 84 (out of 94) courts. This data set contains individual filer information, such as the debtor's name, address, and last four digits of their social security number, and case information, such as the chapter filed, filing date, court, office, outcome (i.e., discharged or dismissed), and judge and trustee names.

To obtain information about the courts that allowed cramdown, we merge our data set with data collected by Goodman and Levitin (2014). This data set comprises all judicial rulings on the permissibility of cramdown from federal bankruptcy, district, and circuit courts between October 1979 and June 1993.

Our final sample comprises Chapter 13 bankruptcy filers in those district courts in which bankruptcy cases are randomly assigned to judges and the Chapter 13 filers for whom we obtain real estate data. To this end, we follow Dobbie and Song (2015) and impose several data filters. First, we drop offices with a single Chapter 13 bankruptcy

judge and exclude filings in courts that assign all cases to a single judge, since in these two situations, there is no randomization of the bankruptcy cases. Second, we exclude office-by-year bins in which a retiring judge's cases have been reassigned with no documentation about the original judge. Third, we drop office-by-year-by-judge bins with fewer than ten cases. Fourth, we restrict our analysis of first-time filers to the period 1989 to 1993, the period in which most of the cramdown rulings occurred. 
Finally, we restrict our sample to Chapter 13 filers that we matched to real estate data purchased from Attom using the address data and the last name provided in the bankruptcy dockets.

These filters leave us with 14,517 Chapter 13 filers in 28 offices, 22 bankruptcy courts, and 18 states. In particular, 6,100 cases in 18 offices in 12 states correspond to courts that adopted mortgage cramdown between 1989 and 1993. Panel A of Figure 1 depicts court locations by state, whereas Panel B shows the states in our sample in which at least one court allowed cramdown. The final sample includes 209 office-yearjudge observations. The number of cases in each office-year-judge bin ranges from 10 to 599, with an average of 195 cases.

\section{[INSERT FIGURE 1 HERE]}

For outcome variables, we rely on two proprietary sources. The first includes foreclosure data from Attom Data Solutions (former RealtyTrac), one of the leading foreclosure listing data providers. Attom collects five types of filings from legal documents submitted by lenders during their foreclosure process. The first two filings, a notice of default (NOD) and a lis pendens (LIS), or written notice of a lawsuit, are submitted before a foreclosure auction. Two of the subsequent filings, a notice of a trustee sale (NTS) and a notice of a foreclosure sale (NFS), are directly associated with a foreclosure auction. Attom also collects information on whether the foreclosed home is purchased by the lender at auction or is real estate owned (REO). From the counties in which Attom has coverage starting in 1989, we successfully match $67 \%$ of the cases using only address data from the bankruptcy dockets and 31\% using the filer's address and last name. This approach ensures that the debtor was the effective owner at the time of the filing. Prior work has used Attom to obtain foreclosure data (e.g., Mian, Sufi, and Trebbi, 2015; Currie and Tekin, 2015).

The second source of outcome and covariate variables is LexisNexis (LN) Public Records. LN aggregates data on over 500 million U.S. individuals, both alive and 
deceased, from a variety of sources, such as birth records, death records, property tax assessment records, criminal records, and voting records. LN provides a panel data set of records for U.S. individuals over time. Specifically, we obtain data about gender, age, history of addresses, and real property records. We successfully match $99 \%$ of filers using the names and social security numbers provided in the bankruptcy dockets. ${ }^{13}$

\subsection{Summary Statistics}

In Column (1), Table 1 presents descriptive statistics for all first-time Chapter 13 bankruptcy filers between 1989 and 1993 along with the statistics for the cramdown and non-cramdown samples in Columns (2)-(4) and (5)-(7), respectively.

We have 14,517 cases in our total sample. Around two-thirds of cases are discharged in the overall sample. The average filer is 42 years old at the time of filing. More than three-quarters of filers are male.

\section{[INSERT TABLE 1 HERE]}

Regarding filer characteristics at the ZIP code level, the average filer in our sample lives in a neighborhood where around $40 \%$ are white, $9 \%$ are single, $7 \%$ have college degrees, and the median income is close to $\$ 23,000$ (in 1980s dollars).

The household characteristics are fairly similar across the cramdown and noncramdown samples, with the exception of gender. In the cramdown sample, $82 \%$ of filers are male, whereas $76 \%$ are male in the non-cramdown sample.

The discharge rate is lower in cramdown courts; whereas around $69 \%$ of filings are discharged in non-cramdown courts, $62 \%$ are discharged in cramdown courts. Thus, the probability of a successful Chapter 13 filing is lower in cramdown courts, where the benefits are likely higher because of the treatment of the underwater portion of a mortgage as unsecured debt.

\footnotetext{
${ }^{13}$ Prior work has used LexisNexis to obtain personal data on executives (Cronqvist, Makhija, and Yonker, 2012; Yermack, 2014), fund managers (Pool, Stoffman, and Yonker, 2012; Chuprinin and Sosyura, 2018), and financial journalists (Ahern and Sosyura, 2015).
} 


\section{Research Design}

Following Dobbie and Song (2015), we estimate the effect of receiving Chapter 13 bankruptcy protection with a principal reduction. We exploit the fact that some U.S. bankruptcy courts use a blind rotation system to assign cases to judges within offices. Although there are standard principles by which judges evaluate and dismiss bankruptcy cases, the variation in the interpretation of these principles across judges is substantial (Sullivan, Warren, and Westbrook, 1994; Norberg and Compo, 2007; Chang and Schoar, 2013).

Ordinary least squares specifications of bankruptcy post-filing outcomes on whether the debtor receives Chapter 13 bankruptcy protection in courts that allowed cramdown is problematic for several reasons. For example, an omitted variable bias may occur because of unobserved characteristics that can affect post-filing outcomes. To overcome such identification problems, our research design uses the random assignment of judges. In particular, we exploit the differences in judge discharge rates (i.e., leniency) as an instrument for receiving cramdown in Chapter 13, within courts that allowed principal mortgage reduction, through a two-stage least squares approach.

Following the literature, we estimate judge styles every year by omitting the own observations to address the own-observation bias problem. ${ }^{14}$ We define the judge's leniency of filing $i$ as the leave-one-out fraction of filings granted by judge $j$ in court $c$ and year $t$ :

$$
\text { Leniency } y_{i c j t}=\frac{1}{n_{c j t}-1}\left(\sum_{k=1}^{n_{c j t}} D_{k}-D_{i}\right)-\frac{1}{n_{c t}-1}\left(\sum_{k=1}^{n_{c t}} D_{k}-D_{i}\right),
$$

where $D_{i}$ is an indicator variable for discharge, $n_{c t}$ is the number of cases in court $c$ in year $t$, and $n_{c j t}$ is the number of cases by judge $j$ in year $t$. We estimate the judge's

\footnotetext{
${ }^{14}$ See, for example, Kling (2006); Doyle (2007); David and Houseman (2010); Chang and Schoar (2013); Dahl, Kost $\varnothing l$, and Mogstad (2014); French and Song (2014); Aizer and Doyle Jr (2015); Maestas, Mullen, and Strand (2013); Dobbie and Song (2015); Dobbie, Goldsmith-Pinkham, and Yang (2017), and Cheng, Severino, and Townsend (2019).
} 
leniency for each year during the period from 1989 to 1993.

Subsequently, we estimate the causal effect of discharge in Chapter 13 bankruptcy through a two-stage least squares regression using the judge's leniency as an instrumental variable for bankruptcy protection. Specifically, we focus this analysis only on offices that allowed cramdown. Therefore, the second-stage estimating equation is

$$
y_{i}=\alpha_{o t}+\beta \widehat{D}_{i}+\gamma^{\prime} X_{i}+\varepsilon_{i}
$$

where $y$ is consumer $i$ 's outcome in the period of interest (e.g., foreclosure within five years after filing), $D$ is an indicator of whether the Chapter 13 case was discharged, $\alpha_{o t}$ are the office-by-month-of-filing fixed effects, and $X$ is a vector of pre-treatment covariates. $\beta$ is the local average treatment effect (LATE) of receiving discharge in Chapter 13 for filers whose outcomes are altered by judge assignment (Imbens and Angrist, 1994). The first-stage estimating equation is

$$
D_{i}=\alpha_{o t}+\delta \text { Leniency }_{i c j t}+\gamma^{\prime} X_{i}+\varepsilon_{i}
$$

where Leniency is the systematic component of judge behavior. To account for any serial correlation across filers at the level of randomization in both the first and second stages, we cluster standard errors at the office-by-judge level.

The three main identifying assumptions are (a) judge assignments are associated with bankruptcy protection, (b) judge assignments only impact debtor outcomes through the probabilities of receiving bankruptcy protection, and (c) the monotonicity assumption.

The exclusion restriction implies that the judge's leniency is unrelated to unobservable determinants of future outcomes. To partially test for this assumption, we estimate in Table 2 whether any pre-treatment individual- or local-level characteristics, such as age, gender, education, and income, can explain judge leniency. We control 
for office-by-month-of-filing fixed effects and cluster standard errors at the office-judge level. None of our covariates is significantly related to leniency, and a joint $F$-test has a $p$-value of $0.3108 .^{15}$ We discuss the relevance of judge assignments in more detail in Section 5.1.

\section{[INSERT TABLE 2 HERE]}

The exclusion restriction might be violated if the judge's leniency affects debtor outcomes through variables other than bankruptcy protection. For example, if more lenient judges are also more likely to provide financial counseling to debtors, which might also affect an individual's outcome. Since judges typically only interact with debtors at the confirmation hearing, it seems unlikely that judges would influence debtors other than through their ruling on the bankruptcy filing.

Finally, to identify a local average treatment effect, we must assume monotonicity. In our setting, the monotonicity assumption is that the probability of debt being discharged in Chapter 13 does not decrease when assigned to a relatively more lenient judge. ${ }^{16}$ A partial test of the monotonicity assumption is that the first-stage estimates should be non-negative for different subsamples (Dahl, Kostøl, and Mogstad, 2014). Section 6.2 provides evidence of a positive first stage based on filer characteristics.

The local average treatment effect $\beta$ in Equation (2) captures the total impact of Chapter 13 discharge on debtor's future outcomes. Thus, it includes the direct effects of cramdown as well as the indirect effect of the other debt discharge. We compare in Section 6 the outcomes between cramdown and non-cramdown courts to shed light on the importance of cramdown relative to other features of the bankruptcy discharge.

\footnotetext{
${ }^{15}$ In Section 5.2, we also show that adding controls to the regressions do not lead to significant changes in our estimates, consistent with the hypothesis that cases are randomly assigned to judges (Dahl, Kostøl, and Mogstad, 2014).

${ }^{16}$ Without the monotonicity assumption, the IV estimator will deliver a weighted average of the marginal treatment effects (Angrist, Imbens, and Rubin, 1996).
} 


\section{Effect of Discharge on Cramdown Courts}

We discuss in this section the effects of bankruptcy discharges in cramdown courts. Households that desire to keep their homes typically prefer to file for Chapter 13 instead of Chapter 7 bankruptcy. This preference is further strengthened if courts allow the discharge of the underwater portion of the mortgage through cramdowns.

Mortgage cramdown is beneficial for homeowners because it reduces the debt burden if their mortgage debt exceeds the fair value of the home. However, homeowners will still need to make their regular mortgage payments to avoid foreclosure. Furthermore, refinancing a mortgage is not typically possible immediately after filing for Chapter 13 bankruptcy due to the deterioration of the credit score and because of the lack of sufficient home equity.

\subsection{First Stage}

Figure 2 illustrates the relevance of the judge's leniency for bankruptcy discharges, aggregated at the judge-year level. The figure shows the relation between the residualized bankruptcy discharge rate (i.e., $\varepsilon_{i}$ from Equation (3) averaged for each judge-year level) against the leave-one-out measure of the judge's leniency (i.e., Leniency Licjt $_{\text {from Equa- }}$ tion (1) averaged for each judge-year level). The regression in Equation (3) includes office-by-month fixed effects. By purging month and office effects, this procedure isolates the variation among judges in the same office at the same time. Panel A depicts the first-stage relation without demographic controls, and Panel B shows the relation with controls for age; gender; the percentages of white, single, and college-educated inhabitants; and the ZIP-code-level logarithm of the median income. We observe a strongly positive relation between the judge's leniency and residualized bankruptcy discharge both before and after, including control variables.

[INSERT FIGURE 2 HERE] 
Interestingly, Figure 2 shows that the judge's leniency has a very broad range from -0.3 to 0.6 . Thus, the discharge rate for the most lenient judges is 60 percentage points higher than that for the other judges in the same office at the same time, and the discharge rate for the strictest judges is 30 percentage points lower than that of their peer judges. This substantial range in lenience demonstrates important differences in the interpretation of the standard principles of bankruptcy across judges. We also find significant persistence in judge leniency. Figure 3 depicts current and lagged judge discharge rates, with each point representing a separate judge by year observation.

\section{[INSERT FIGURE 3 HERE]}

Table 3 presents the linear-probability relation between bankruptcy discharge and the judge's leniency using disaggregated individual-level data. The standard errors are clustered at the office-by-judge level.

Column (1) presents the estimates without any controls besides office-by-month fixed effects. We find that a one-percentage-point increase in the judge's leniency in other filings increases the probability that a debtor receives Chapter 13 protection by 0.894 percentage points. The estimates are similar when we include controls at the individual level (Column (2)) and at the ZIP code level (Column (3)). The leave-oneout measure of leniency, filer characteristics, and office-by-month fixed effects explain only around $22 \%$ of the variation in discharge rates. Thus, a substantial proportion of the variation cannot be explained by observable variables.

\section{[INSERT TABLE 3 HERE]}

Interestingly, Chapter 13 filings by female debtors are less likely to be discharged than those of male debtors. The discharge rate for female filers is around 4 percentage points lower than the rate for male filers after controlling for various neighborhood characteristics. Furthermore, filings by debtors living in ZIP codes with a larger fraction of white inhabitants are more likely to be successful. These differences could be due to 
unobserved characteristics but also due to discrimination. ${ }^{17}$ Judges may impose higher qualification thresholds on individuals who represent minority groups in bankruptcy filings. ${ }^{18}$

Altogether, Figure 2 and Table 3 confirm that the judge's leniency is highly predictive of receiving bankruptcy protection. Thus, the judge's leniency satisfies the relevance criterion.

\subsection{Foreclosure Rates}

To study whether a Chapter 13 discharge in cramdown courts reduces future foreclosures, we run the two-stage least squares specification, summarized in Equations (2) and (3). Table 4 reports the estimates of the impact of Chapter 13 bankruptcy protection in courts that allowed mortgage cramdown on homeowners' distress events.

We use two different distress events: foreclosures (Panel A) and involuntary sales (Panel B). ${ }^{19}$ Home foreclosure is an indicator for a filer's home receiving a notice of default, transfer or sale, or having been transferred to a real estate owned after the bankruptcy filing. Involuntary sales capture cases where homeowners sell their properties for less than the amount due on the mortgage after the bankruptcy filing. The controls include age; gender; the percentage of the ZIP code's population that is white, single, and college educated; and the median log income in the ZIP code. All regressions include office-by-month-of-filing fixed effects, and the standard errors are clustered at the office-by-judge level. ${ }^{20}$

\footnotetext{
${ }^{17}$ Agarwal, Chomsisengphet, McMenamin, and Skiba (2010) use information on name and ZIP code to calculate a Bayesian-likelihood estimate of individual debtors' race. Controlling for debtor demographics and financial situation, their results show that white judges are $21 \%$ more likely to dismiss the Chapter 13 petition of an African American debtor relative to a white debtor.

${ }^{18}$ In untabulated results, we hand-collect data on the gender of the judges in our sample. We find that, on average, the gender of the judge does not impact the probability of receiving Chapter 13 protection. In addition, we find no significant evidence of an interaction effect on the judge's gender and the filer's gender.

${ }^{19}$ In our sample, $69 \%$ of involuntary sales are associated with foreclosure events.

${ }^{20}$ In panel A of Figure IA.1 in the Internet Appendix, we find similar results if we use a distress measure that includes other events, such as real-estate-owned (REO) liquidation, besides the foreclosure events.
} 


\section{[INSERT TABLE 4 HERE]}

Panel A of Table 4 reports that the discharge reduces foreclosures by 26 percentage points after three years and by 29 percentage points after five years. The estimates are highly statistically significant and very similar if we include additional demographic control variables. Furthermore, the results are also economically meaningful, as the average three- and five-year foreclosure rates in the sample of Chapter 13 dismissed filers are 23.8 and 26.2 percentage points, respectively. ${ }^{21}$ Figure IA.2 in the Internet Appendix plots average home foreclosure rates for discharged and dismissed Chapter 13 cases. At three years post-filing, foreclosure rates for discharged homeowners are 2.5 percent, relative to around 23 percent for dismissed filers. Overall, our estimates of the five-year reduction of 29 percentage points in courts that allow cramdown are comparable to Dobbie and Song (2015), who find a decrease in five-year foreclosure rates of 19 percentage points between 1992 and 2005 in successful Chapter 13 filings.

Panel A of Figure 4 depicts the yearly changes in home foreclosure rates after mortgage discharge in cramdown courts. The economic magnitude of the discharge effect is relatively small in the first year but grows substantially over the next two years. The discharge effect stabilizes after four years.

\section{[INSERT FIGURE 4 HERE]}

Panel B of Table 4 and Figure 4 report similar effects for involuntary sales. For example, bankruptcy discharge decreases the probability of an involuntary sale over the first five years by 26 percentage points, relative to the control group mean of 19 percentage points.

We also study the heterogeneity of the discharge effect of Chapter 13 in cramdown courts on foreclosures in recession periods relative to non-recession periods. Table IA.1 in the Internet Appendix shows that the difference is not statistically significant.

\footnotetext{
${ }^{21}$ Because most of foreclosures result in a change of address, we use the dismissed filer mean for reference, as we only observe an individual address at the time of filing.
} 
The magnitude of the discharge effects could also depend on a state's recourse status or homestead exemption generosity. Panel A of Table IA.2 in the Internet Appendix shows that the differences in the discharge effects are not statistically significant between recourse and non-recourse states. In Panel B we test whether the discharge effects are different between states with below- and above-median homestead exemptions. The classification of homestead exemptions use data from 1996 and the medians are based on states in our sample. We find that the estimates are statistically indistinguishable between states with different exemption generosity.

\subsection{Additional Benefits}

The debt relief provided by successful Chapter 13 filings in cramdown courts may have additional benefits for debtors. Mortgage discharge can stabilize the living arrangements and circumstances of households. For example, households benefiting from discharge may avoid having to move to a new home. Moving can be especially costly for families with school-aged children, so precluding a move would be beneficial. Furthermore, these households may have the flexibility to move to better neighborhoods or purchase new properties. Finally, the stress of foreclosure or the resultant moves may increase the propensity to commit crimes and even worsen the mortality rate for households.

Table 5 reports the effects of discharge in cramdown courts on these other outcomes. The empirical specification is again the two-stage least squares summarized in Equations (2) and (3), where we use alternative outcome variables.

\section{[INSERT TABLE 5 HERE]}

We find that households with discharged debt are significantly less likely to move to new addresses over the five years after filing. For example, the propensity to move to a new address declines by around 20 percentage points for discharged debtors, a $25 \%$ 
decrease from the control group mean. Households are also less likely to voluntarily sell their homes, which excludes short sells.

Furthermore, we find that even if discharged debtors are less likely to change their place of residence, if they move, they are more likely to move to ZIP codes with higher median income levels. This result indicates that bankruptcy discharge with cramdown increases the household's flexibility to enhance their living arrangements. In contrast, we do not find that Chapter 13 discharge affects the probability of households purchasing new properties. One interpretation is that these households face significant financial constraints that prevent them from purchasing new properties in the years following a bankruptcy filing.

Refinancing a mortgage is difficult during the first years after a bankruptcy filing (e.g., requires judge approval). Consistent with this, we find no significant increase in refinancing in the first three post-filing years. However, we find a significant increase in refinancing activity after five years. Homeowners start to refinance their mortgage debt as they build up home equity and as their credit scores improve. In addition, after five years, filers have completed their repayment plan. Thus, they do not require judge approval for refinancing.

Debt discharge in cramdown courts also has broader benefits for households, as the rate of criminal filings decrease substantially over the subsequent years. ${ }^{22}$ On the other hand, we do not find a significant impact on mortality, given that most filers are relatively young.

\subsection{Filer Characteristics}

The benefit of mortgage discharge in cramdown courts may differ among households with varying characteristics. Gender might matter because judges may treat female

\footnotetext{
${ }^{22}$ Criminal filing is an indicator equal to one if the individual committed a traffic infraction or the filer is found guilty of a misdemeanor or a felony. In terms of types of crime: $53 \%$ are traffic infractions (e.g., speeding, DUI), 26\% are misdemeanors, $8 \%$ are felonies, and $13 \%$ are not specified.
} 
filers differently than male filers, as documented in Table 3. Female filers might also be more reluctant to move, as they are more likely to be the main caregivers of dependent children. Similarly, foreclosures may be more disrupting for younger debtors with school-aged children. Finally, foreclosures could be more costly for individuals living in single-family homes, since they may have customized their homes according to their own preferences.

Table 6 shows that while the discharge benefits are substantial across all the different demographic groups, female filers benefit more from discharge. For example, foreclosures decline by 11.3 percentage points more for female than for male filers (i.e., $36.1 \%$ vs. $24.8 \%$ ) and involuntary sales decline by 19.3 percentage points more for female than for male filers (i.e., $41.0 \%$ vs. 21.7\%). Although these gender differences are economically significant, they are only statistically significant for involuntary sales. They could occur because female filers may have a stronger preference to remain in their homes or because of discrimination, as judges may require a higher threshold for female filers to qualify for Chapter 13 debt discharge for female filers, as shown in Table $3 .{ }^{23}$ The differential treatment of female filers mostly by male judges may be due to systematic patterns of "in-group" tolerance, as discussed by Egan, Matvos, and Seru (2018) in the context of misconduct in the financial advisory industry.

\section{[INSERT TABLE 6 HERE]}

Filers below 50 years old exhibit larger declines in the three-year foreclosure rate, although the differences are not statistically significant. Similarly, filers owning singlefamily homes also exhibit larger declines in foreclosure rates than owners in multi-family units (e.g., condominiums). Because of the limited sample size, these differences are also not statistically significant.

\footnotetext{
${ }^{23} \mathrm{~A}$ potential concern with this result is how we define gender for joint filers. For joint filers, we classify the filer's gender based on the first filer in the bankruptcy docket. To mitigate this concern, we estimate the effects of receiving Chapter 13 protection for female, male, and joint filers. As in Table 6 , in untabulated results, we find a similar difference in post-filing outcomes between female and male filers. We also document a difference between female and joint filers.
} 


\section{Differential Effects between Cramdown and Non- Cramdown Courts}

Our previous results show that debt discharge in cramdown courts has a large impact on the economic circumstances of households. However, whether these effects are driven by the cramdown provisions or by other features of debt restructuring through Chapter 13 is unclear. To address this question, we combine our samples from cramdown and non-cramdown courts and study whether the effects differ across the two samples.

\subsection{Differential Foreclosure Effects}

In this section, we exploit both within- and across-district variation in cramdown adoption by estimating the impact of Chapter 13 bankruptcy protection in cramdown courts relative to non-cramdown courts. We augment Equation (2) by including: 1) the interaction of an indicator of whether the Chapter 13 case was discharged $\left(D_{i}\right)$ with an indicator of whether the district court allowed cramdown at the time of filing and 2) the interaction of $D_{i}$ with an indicator of whether the district court did not allow cramdown at the time of filing. We instrument for the interaction of the discharge indicator and the cramdown (and non-cramdown) indicator variable using the interaction between judge leniency and the cramdown (and non-cramdown) indicator.

Figure 5 provides the dynamics of the impact of debt discharge on the two distress proxies between cramdown and non-cramdown courts. Debt discharge is substantially more beneficial in cramdown courts because of the reduction of debt for underwater homeowners. Table 7 confirms that the impact of debt discharge is substantially more pronounced in cramdown courts. For example, the three-year foreclosure rate declines by around 27 percentage points for cramdown courts and by four percentage points for non-cramdown courts. The difference in the two coefficients is highly statistically significant, as indicated by the small $p$-values. In addition, the results are robust if 
we exclude large states, such as California. These findings suggest that most of the discharge effect is due to the principal reduction.

\section{[INSERT FIGURE 5 HERE]}

One potential issue of these results is that the propensity to file for Chapter 13 may differ across cramdown courts and non-cramdown courts. For example, more households may file for Chapter 13 bankruptcy in cramdown courts because of the potential discharge of the underwater portion of the mortgage. These additional filers therefore may be less distressed. Furthermore, trustees and judges in cramdown courts may follow different debt restructuring strategies. Judges may be more likely to approve a restructuring plan in cramdown courts since these plans are more likely to succeed if a write-down of mortgage debt is possible. However, Table 1 shows that judges discharge a smaller proportion of cases in cramdown courts than in non-cramdown courts.

\section{[INSERT TABLE 7 HERE]}

One concern is that the effects documented in Table 7 could be explained by acrossstate differences. We focus on states with both cramdown and non-cramdown courts to investigate this hypothesis. Thus, we are not comparing Chapter 13 effects between cramdown and non-cramdown states. Since the cramdown adoption was staggered in our sample period, we exploit in this test the variation across districts in cramdown adoption and within-district variation in courts that allowed cramdown. The estimates, reported in Table 8, are similar to those in Table 7. These findings support that acrossstate differences do not explain the documented effects.

\section{[INSERT TABLE 8 HERE]}

Another concern is that bankruptcy filers could be different across these two groups. To partially test for this sample selection hypothesis, we exploit district variation in cramdown status in a difference-in-differences approach on observable characteristics 
(age and gender) and chapter of filing composition. ${ }^{24}$ Table IA.3 in the Internet Appendix shows no evidence of changes in observable covariates or in the ratio between Chapter 7 and 13 filings, both in our sample and on the complete PACER sample.

Moreover, to investigate whether the mortgage cramdown feature significantly increased Chapter 13 bankruptcy filings, we study the number of these filings around the Supreme Court decision of June 1993 that prohibited mortgage cramdown in all states. Figure 6 shows no evidence of bunching in the number of filings around the 1993 Supreme Court decision. This result is also consistent with the small effect of cramdown on credit supply and cost of credit documented by Goodman and Levitin (2014) and Li, Tewari, and White (2014). Altogether, these results do not support the sample selection hypothesis.

\section{[INSERT FIGURE 6 HERE]}

\subsection{Compliers versus Non-Compliers}

Our IV estimates should be interpreted as the local average treatment effects of filers receiving Chapter 13 protection in cramdown courts whose outcomes are altered by judge assignments (Imbens and Angrist, 1994). Learning about the characteristics of the complier group is of interest. In addition, examining the covariates of the compliers allows us to compare the characteristics of the marginal filers of Chapter 13 in cramdown and non-cramdown courts during our sample period.

Table 9 presents characteristics of compliers, following Angrist and Pischke (2008). Panel A reports the distributions of filers in cramdown courts. Column (1) presents the proportion of the sample within each gender and age group (i.e., $P(X=x)$ ). For example, $43.3 \%$ of filers in cramdown courts are men between 35 and 50 years of age,

\footnotetext{
${ }^{24} \mathrm{As}$ our treatment, in this case, is at the district level, we cluster the standard errors at the district level (Abadie, Athey, Imbens, and Wooldridge, 2017). Since we have 22 districts in our sample, we follow MacKinnon and Webb (2017) and apply the correction for the number of clusters by using ordinary wild bootstrap.
} 
whereas $9.2 \%$ of filers are women between 35 and 50 years. Column (2) shows the first-stage estimates for each gender and age group, corresponding to Table 3. These positive first-stage estimates for different subgroups are consistent with the monotonicity assumption. In addition, the judge's leniency in cramdown courts is less predictive of discharge for female filers between the ages of 35 and 50 than for any other demographic group. Column (3) reports the distribution of compliers by gender and age (i.e., $\left.P\left(X=x \mid I_{1}>I_{0}\right)\right)$, calculated as the first-stage estimate for the gender-age groups times the sample share, divided by the overall first-stage estimate. Although $9.2 \%$ of filers are women between the ages of 35 and 50, only $6.6 \%$ of compliers are women in this age group. The last column, which is defined as the ratio between the relative likelihood of a filer belonging to a particular gender and age group in the complier group compared with the relative likelihood in the sample, confirms that women between 35 and 50 years are underrepresented in the sample of compliers in cramdown courts.

\section{[INSERT TABLE 9 HERE]}

Panel B reports the results for filers in non-cramdown courts. The estimates show that males are somewhat overrepresented in the complier group, as in the cramdown courts. However, the most important difference relative to the compliers in the cramdown courts is the composition of female filers. Women aged 35-50 are equally represented in the complier group, while women older than 50 are unrepresented in the complier group.

\subsection{Mechanisms}

In the previous sections, we document substantial benefits for homeowners of successful Chapter 13 filings in cramdown courts. In addition, the comparison of the ex-post effects of successful filers in courts with and without cramdown provides evidence that the

principal reduction through personal bankruptcy offers substantial benefits for homeowners. 
Two potential explanations for the large economic magnitude of the effects merit discussion. The first, which we call the liquidity hypothesis, is that the reduction in short-term payments helps debtors by alleviating liquidity constraints. The second is that the reduction in long-term obligations helps debtors by reducing their debt relative to the value of their homes. We call this second explanation "the debt overhang hypothesis" (Ganong and Noel, 2018; Dobbie and Song, 2020; Ganong and Noel, 2020).

Two features in the setting shed light on the mechanism. First, in courts that allowed cramdown, the negative equity portion of the mortgage is classified as unsecured debt and thus is dischargeable. Second, in cramdown, the loan will not be modified. That means debtors must continue making monthly payments following the terms of the original loan until the principal payments total the present value of the collateral. Thus, cramdown primarily provides debt relief in the form of the second hypothesis, and it seems that the debt overhang channel plays an important role in explaining our results.

There are two challenges to this interpretation. First, debtors could have also received some unsecured debt relief, in addition to the principal reduction in Chapter 13. The comparison of cramdown in Chapter 13 to standard Chapter 13 (as shown in Figure 5), where we find that the impact of cramdown is substantially larger on foreclosures, alleviates this concern. ${ }^{25}$

The second challenge is that debtors could have received unsecured or secured credit following Chapter 13 bankruptcy. However, in the case of unsecured debt, after filing for Chapter 13, lenders can cancel the debtor's account. Also, the trustee may confiscate the filer's credit cards since the trustee must supervise the debtor's finances for three to five years (Elias, 2013). In addition, Dobbie, Goldsmith-Pinkham, and Yang (2017) do not find an effect on unsecured credit following Chapter 13. In the case of se-

\footnotetext{
${ }^{25}$ Another challenge is that successful Chapter 13 cases in cramdown courts could also have done lien stripping of second and third mortgages. However, this procedure can also be done in standard Chapter 13 cases, and thus, comparing the discharge effect of Chapter 13 in cramdown versus non-cramdown lessens this concern.
} 
cured lending, it could be that debtors refinanced their mortgages following cramdown. However, as shown in Table 5, refinancing is typically unavailable in the first post-filing years following Chapter 13, and it is difficult in practice. For example, the debtor typically needs to have a good credit score, which is unlikely after receiving a bankruptcy flag, and sufficient home equity to be approved for a mortgage. Furthermore, the filer requires judge approval. Thus, it seems unlikely that debtors receive substantial access to external financing at least during the first years following Chapter 13.

A caveat of our findings is that our setting does not allow us to study the role of liquidity constraints in foreclosure since we are estimating the impact of principal reductions. Consequently, our results do not reject the importance of liquidity constraints as a potential determinant for homeowner default. However, we provide evidence that debt overhang considerations play a role in explaining homeowner default.

Finally, one question that this discussion raises is why our estimates of the principal reduction in Chapter 13 are substantially larger relative to the documented effect of principal reduction policies implemented during the Great Recession. One potential explanation is that the principal reduction programs employed during the financial crisis (e.g., HAMP) were relatively small and thus, homeowners were probably still underwater following these loan modifications. In contrast, homeowners in the cramdown courts had their total negative equity portion forgiven in Chapter 13 bankruptcy and therefore had greater incentives to avoid default.

\subsection{Cramdown Proposal during the Financial Crisis}

The United States experienced an unprecedented number of home foreclosures during the Great Recession of 2007-2009. The government implemented various policies to reduce defaults and the deadweight losses of foreclosures (e.g., HAMP, HARP). However, Agarwal et al. (2015) and Agarwal et al. (2017) show that various frictions hampered the impact of these policies. One alternative proposal in 2008 was to allow mortgage 
cramdown by judges through Chapter 13 bankruptcy. The proposal passed the House of Representatives but failed in the Senate. In this section, we provide a back-of-theenvelope calculation of the potential benefits that cramdown would have had during the financial crisis.

To estimate the number of foreclosures avoided, we extrapolate our estimates in a partial equilibrium approach. We make several assumptions: First, we assume similar effects across groups (i.e., compliers vs. non-compliers). Second, we assume that the effect of cramdown would have been the same during the Great Recession as during our sample period. Third, the number of total filers is the same with and without cramdown. Fourth and finally, we do not consider general equilibrium effects (e.g., credit supply, interest rate, home values, spillover effects of foreclosures).

We start with 7.6 million total filings of Chapters 7 and 13 bankruptcies between 2008 and 2013. The homeownership rate during this time period equaled $64 \%$, resulting in around 4.9 million filings by homeowners, which would be expected to file for Chapter 13. During this time period $49 \%$ of Chapter 13 filings were discharged, resulting in 2.4 million successful bankruptcy filings. Table 7 documents that cramdown reduced fiveyear foreclosure rates by around 24 percentage points relative to non-cramdown. Using this estimate, we find a reduction of around 0.57 million foreclosures over the five years after the bankruptcy.

Our estimates potentially underestimate the effect of cramdown during the Great Recession since the decline in house prices was greater during this time period. ${ }^{26}$ Furthermore, the proportion of households that filed for Chapter 13 bankruptcy could have increased with a more generous bankruptcy procedure. This analysis might also potentially overestimate the effect of cramdown since we identify the causal impact of cramdown for the compliers. However, our estimates for the compliers are relevant for

\footnotetext{
${ }^{26}$ Although the average drop in home prices was not as pronounced during our sample period as during the Great Recession, there were markets in our sample, such as Massachusetts, where house prices declined by 23\% between 1988 and 1993 (Foote, Gerardi, and Willen, 2008).
} 
policy since reforms aimed at introducing cramdown will likely have the largest effect on debtors on the margin of program participation. ${ }^{27}$

\section{Discussion}

The assessment of consumer bankruptcy laws typically involves the evaluation of two effects. The first effect is that bankruptcy provides partial insurance by helping households smooth consumption when hit by a particularly adverse event (e.g., health shocks). The second effect is the greater borrowing costs due to a higher risk of default, which reduces households' ability to smooth expected changes in earnings (e.g., Athreya, 2002; Li and Sarte, 2006; Livshits, MacGee, and Tertilt, 2007; Chatterjee and Gordon, 2012; Gross, Kluender, Liu, Notowidigdo, and Wang, 2019).

Our paper focuses on the first effect of changes in the generosity of the personal bankruptcy code: The ex-post benefits of cramdown in Chapter 13. We document substantial ex-post effects for marginal filers on household distress. Since filers are substantially more likely to keep their homes, cramdown also stabilizes living arrangements. Given the high costs of foreclosure (Diamond, Gureny, and Tan, 2020), particularly for marginal debtors who are most responsive to foreclosure mitigation policies and the negative spillovers of foreclosure, cramdown has significant ex-post benefits for homeowners. ${ }^{28}$

However, this policy might be costly for borrowers ex-ante or could hurt other market participants ex-post. In particular, the introduction of cramdown could lead to higher borrowing costs. Goodman and Levitin (2014) and Li, Tewari, and White (2014) find relatively small effects of cramdown on interest rates and other mortgage terms.

\footnotetext{
${ }^{27}$ Cramdown potentially would have pushed more banks to modify mortgages, and thus our partial equilibrium analysis could underestimate the overall reduction in foreclosures by cramdown.

${ }^{28}$ Mian, Sufi, and Trebbi (2015) and Guren and McQuade (2020) find that foreclosures have large market-level effects. While Immergluck and Smith (2006), Campbell, Giglio, and Pathak (2011), Harding, Rosenblatt, and Yao (2009), Anenberg and Kung (2014), Gerardi, Rosenblatt, Willen, and Yao (2015), and Gupta (2019) provide evidence of localized foreclosure spillovers.
} 
The former finds that when cramdown was allowed, home loans had interest rates that were 16 basis points higher, and the latter finds that when the Supreme Court abolished mortgage cramdown, this led to a short-term reduction of $3 \%$ in mortgage interest rates and an increase of $1 \%$ in mortgage approval rates. Furthermore, Levitin (2009) argues that the market is unlikely to price against bankruptcy modifications since lenders face smaller losses from bankruptcy modifications than from foreclosures.

Mayer, Morrison, and Piskorski (2009) discuss some risks of introducing cramdown legislation during the Great Recession. They state that cramdown could generate a massive number of bankruptcy filings and impose large burdens on bankruptcy judges and trustees. As mentioned, Figure 6 shows no significant bunching in the bankruptcy filings in cramdown courts in June 1993. Furthermore, bankruptcy filings in cramdown courts did not significantly decrease after the Supreme Court decision, as Chapter 13 bankruptcy became less beneficial. This result is consistent with Indarte (2019) who finds only a small incidence of strategic bankruptcy filings. In addition, during our sample period, bankruptcy was substantially less popular, which also alleviates concerns about strategic behavior from bankruptcy filers.

Furthermore, Mayer, Morrison, and Piskorski (2009) discuss that cramdown mortgage modifications would be more aggressive than other types of modifications and would impose excessive losses on lenders. The question of whether lenders benefit from cramdown depends on the magnitude of the underwater portion of the debt and on the preferences of households to remain in their homes. If the cost due to negative equity is less than the private benefits, borrowers would not walk away and default, but rather continue making their mortgage payments even if the value of their home is less than what they owe. In this case, cramdown would impose a loss on the lenders equal to the amount that is being written off. If the underwater portion of the mortgage is relatively large, households would likely decide to default on their mortgage if no cramdown is offered. The losses to the lenders and to the mortgage investors would in this case 
likely be higher than the underwater portion of the loan due to various frictions of the foreclosure process. ${ }^{29}$

\section{Conclusions}

We document that mortgage cramdown has significant ex-post benefits for bankruptcy filers. We find that in cramdown courts, a successful Chapter 13 filing reduces the fiveyear foreclosure rate by 29 percentage points and reduces the number of moves postbankruptcy. We also find that cramdown explains the vast majority of the reduction in foreclosure rates for Chapter 13 filers. Our results indicate that cramdown is an effective policy for reducing home foreclosures and enhancing the living standards of bankruptcy filers. Our results suggest that debt overhang considerations play an important role in explaining homeowner default.

\footnotetext{
${ }^{29}$ For example, Campbell, Giglio, and Pathak (2011) show that houses sold after foreclosure, or close in time to the death or bankruptcy of a seller, suffer discounts of around 27 percent of the value of a home.
} 


\section{References}

Abadie, A., S. Athey, G. W. Imbens, and J. Wooldridge (2017). When should you adjust standard errors for clustering? Technical report, National Bureau of Economic Research.

Abel, J. and A. Fuster (2018). How do mortgage refinances affect debt, default, and spending? Evidence from HARP. Technical report. Working Paper.

Agarwal, S., G. Amromin, I. Ben-David, S. Chomsisengphet, T. Piskorski, and A. Seru (2017). Policy intervention in debt renegotiation: Evidence from the home affordable modification program. Journal of Political Economy 125(3), 654-712.

Agarwal, S., G. Amromin, S. Chomsisengphet, T. Landvoigt, T. Piskorski, A. Seru, and V. Yao (2015). Mortgage refinancing, consumer spending, and competition: Evidence from the home affordable refinancing program. Technical report, NBER Working Paper 21512.

Agarwal, S., S. Chomsisengphet, R. McMenamin, and P. M. Skiba (2010). Dismissal with prejudice? Race and politics in personal bankruptcy. Technical report, SSRN.

Agarwal, S., J. He, T. F. Sing, and J. Zhang (2018). Gender gap in personal bankruptcy risks: Empirical evidence from singapore. Review of Finance 22(2), 813-847.

Ahern, K. R. and D. Sosyura (2015). Rumor has it: Sensationalism in financial media. The Review of Financial Studies 28(7), 2050-2093.

Aizer, A. and J. J. Doyle Jr (2015). Juvenile incarceration, human capital, and future crime: Evidence from randomly assigned judges. The Quarterly Journal of Economics 130(2), 759-803.

Anenberg, E. and E. Kung (2014). Estimates of the size and source of price declines due to nearby foreclosures. The American Economic Review 104(8), 2527-51. 
Angrist, J. D., G. W. Imbens, and D. B. Rubin (1996). Identification of causal effects using instrumental variables. Journal of the American Statistical Association 91(434), $444-455$.

Angrist, J. D. and J.-S. Pischke (2008). Mostly Harmless Econometrics. Princeton University Press.

Athreya, K. B. (2002). Welfare implications of the bankruptcy reform act of 1999. Journal of Monetary Economics 49(8), 1567-1595.

Bhutta, N., J. Dokko, and H. Shan (2017). Consumer ruthlessness and mortgage default during the 2007 to 2009 housing bust. The Journal of Finance 72(6), 2433-2466.

Campbell, J. Y., S. Giglio, and P. Pathak (2011). Forced sales and house prices. The American Economic Review 101(5), 2108-31.

Chang, T. and A. Schoar (2013). Judge specific differences in chapter 11 and firm outcomes. Technical report, National Bureau of Economic Research Cambridge.

Chatterjee, S. and G. Gordon (2012). Dealing with consumer default: Bankruptcy vs garnishment. Journal of Monetary Economics 59, S1-S16.

Cheng, I.-H., F. Severino, and R. Townsend (2019). How do consumers fare when dealing with debt collectors? Evidence from out-of-court settlements. Technical report, Tuck School of Business Working Paper.

Chuprinin, O. and D. Sosyura (2018). Family descent as a signal of managerial quality: Evidence from mutual funds. The Review of Financial Studies 31(10), 3756-3820.

Cronqvist, H., A. K. Makhija, and S. E. Yonker (2012). Behavioral consistency in corporate finance: CEO personal and corporate leverage. Journal of Financial Economics 103(1), 20-40. 
Currie, J. and E. Tekin (2015). Is there a link between foreclosure and health? American Economic Journal: Economic Policy 7(1), 63-94.

Dahl, G. B., A. R. Kostøl, and M. Mogstad (2014). Family welfare cultures. The Quarterly Journal of Economics 129(4), 1711-1752.

David, H. and S. N. Houseman (2010). Do temporary-help jobs improve labor market outcomes for low-skilled workers? Evidence from "work first". American Economic Journal: Applied Economics 2(3), 96-128.

Diamond, R., A. Gureny, and R. Tan (2020). The effect of foreclosures on homeowners, tenants, and landlords. Technical report. Working Paper.

Dobbie, W., P. Goldsmith-Pinkham, and C. S. Yang (2017). Consumer bankruptcy and financial health. Review of Economics and Statistics 99(5), 853-869.

Dobbie, W. and J. Song (2015). Debt relief and debtor outcomes: Measuring the effects of consumer bankruptcy protection. The American Economic Review 105(3), $1272-1311$.

Dobbie, W. and J. Song (2020). Targeted debt relief and the origins of financial distress: Experimental evidence from distressed credit card borrowers. The American Economic Review 110(4), 984-1018.

Doyle, J. J. J. (2007). Child protection and child outcomes: Measuring the effects of foster care. The American Economic Review 97(5), 1583-1610.

Driscoll, S. (1994). Consumer bankruptcy and gender. The Georgetown Law Journal 83, $525-557$.

Egan, M., G. Matvos, and A. Seru (2018). When Harry fired Sally: The double standard in punishing misconduct. Technical report. Working Paper.

Elias, S. (2013). The new bankruptcy: Will it work for you? Nolo Berkeley CA. 
Elul, R., N. S. Souleles, S. Chomsisengphet, D. Glennon, and R. Hunt (2010). What "triggers" mortgage default? The American Economic Review 100(2), 490-94.

Foote, C. L., K. Gerardi, and P. S. Willen (2008). Negative equity and foreclosure: Theory and evidence. Journal of Urban Economics 64 (2), 234-245.

Foster, C. and R. Van Order (1984). An option-based model of mortgage default. Housing Fin. Rev. 3, 351.

French, E. and J. Song (2014). The effect of disability insurance receipt on labor supply. American Economic Journal: Economic Policy 6(2), 291-337.

Ganong, P. and P. Noel (2018). Liquidity vs. wealth in household debt obligations: Evidence from housing policy in the great recession. Technical report, National Bureau of Economic Research.

Ganong, P. and P. J. Noel (2020). Why do borrowers default on mortgages? A new method for causal attribution. Technical report, National Bureau of Economic Research.

Gerardi, K., K. F. Herkenhoff, L. E. Ohanian, and P. S. Willen (2018). Can't pay or won't pay? unemployment, negative equity, and strategic default. The Review of Financial Studies $31(3), 1098-1131$.

Gerardi, K., E. Rosenblatt, P. S. Willen, and V. Yao (2015). Foreclosure externalities: New evidence. Journal of Urban Economics 87, 42-56.

Goodman, J. and A. Levitin (2014). Bankruptcy law and the cost of credit: The impact of cramdown on mortgage interest rates. The Journal of Law and Economics 57(1), 139-158.

Gross, T., R. Kluender, F. Liu, M. J. Notowidigdo, and J. Wang (2019). The economic consequences of bankruptcy reform. Technical report. NBER Working Paper 26254. 
Gross, T., M. J. Notowidigdo, and J. Wang (2014). Liquidity constraints and consumer bankruptcy: Evidence from tax rebates. Review of Economics and Statistics 96(3), 431-443.

Guiso, L., P. Sapienza, and L. Zingales (2013). The determinants of attitudes toward strategic default on mortgages. The Journal of Finance 68(4), 1473-1515.

Gupta, A. (2019). Foreclosure contagion and the neighborhood spillover effects of mortgage defaults. The Journal of Finance $74(5), 2249-2301$.

Gupta, A. and C. Hansman (2020). Selection, leverage, and default in the mortgage market. Available at SSRN 3315896.

Guren, A. M. and T. J. McQuade (2020). How do foreclosures exacerbate housing downturns? The Review of Economic Studies 87(3), 1331-1364.

Harding, J. P., E. Rosenblatt, and V. W. Yao (2009). The contagion effect of foreclosed properties. Journal of Urban Economics 66(3), 164-178.

Imbens, G. W. and J. D. Angrist (1994). Identification and estimation of local average treatment effects. Econometrica 62(2), 467-475.

Immergluck, D. and G. Smith (2006). The external costs of foreclosure: The impact of single-family mortgage foreclosures on property values. Housing Policy Debate 17(1), 57-79.

Indarte, S. (2019). The impact of debt relief generosity and liquid wealth on household bankruptcy. Available at SSRN 3378669.

Kaplan, G., K. Mitman, and G. L. Violante (2020). The housing boom and bust: Model meets evidence. Journal of Political Economy 128(9), 3285-3345.

Kling, J. R. (2006). Incarceration length, employment, and earnings. The American Economic Review 96(3), 863-876. 
Levitin, A. J. (2009). Resolving the foreclosure crisis: Modification of mortgages in bankruptcy. Wisconsin Law Review, 565-655.

Li, W. and P.-D. Sarte (2006). Us consumer bankruptcy choice: The importance of general equilibrium effects. Journal of Monetary Economics 53(3), 613-631.

Li, W., I. Tewari, and M. J. White (2014). Using bankruptcy to reduce foreclosures: Does strip-down of mortgages affect the supply of mortgage credit? Technical report, National Bureau of Economic Research.

Livshits, I., J. MacGee, and M. Tertilt (2007). Consumer bankruptcy: A fresh start. The American Economic Review 97(1), 402-418.

Luzzetti, M. N. and S. Neumuller (2014). Bankruptcy reform and the housing crisis. Technical report. Working Paper.

MacKinnon, J. G. and M. D. Webb (2017). Wild bootstrap inference for wildly different cluster sizes. Journal of Applied Econometrics 32(2), 233-254.

Maestas, N., K. J. Mullen, and A. Strand (2013). Does disability insurance receipt discourage work? Using examiner assignment to estimate causal effects of SSDI receipt. The American Economic Review 103(5), 1797-1829.

Mayer, C., E. Morrison, and T. Piskorski (2009). A new proposal for loan modifications. Yale Journal of Regulation 26(2), 417-429.

Mayer, C., E. Morrison, T. Piskorski, and A. Gupta (2014). Mortgage modification and strategic behavior: Evidence from a legal settlement with countrywide. The American Economic Review 104(9), 2830-57.

Mian, A., A. Sufi, and F. Trebbi (2015). Foreclosures, house prices, and the real economy. The Journal of Finance 70(6), 2587-2634. 
Mullaugh, E. P. (1994). The feath of mortgage cramdown in chapter 13: Nobelman v. American Savings Bank. Journal of Law and Commerce 14, 141.

Norberg, S. F. and N. S. Compo (2007). Report on an empirical study of district variations, and the roles of judges, trustees and debtors' attorneys in chapter 13 bankruptcy cases. American Bankruptcy Law Journal 81, 431.

Piskorski, T. and A. Seru (2018a). Debt relief and slow recovery: A decade after lehman. Technical report. NBER Working Paper 25403.

Piskorski, T. and A. Seru (2018b). Mortgage market design: Lessons from the great recession. Brookings Papers on Economic Activity, 429-499.

Pool, V. K., N. Stoffman, and S. E. Yonker (2012). No place like home: Familiarity in mutual fund manager portfolio choice. The Review of Financial Studies 25(8), 2563-2599.

Riddiough, T. J. (1991). Equilibrium Mortgage Default Pricing with Non-optimal Borrower Behavior. Ph. D. thesis, The University of Wisconsin-Madison.

Sullivan, T. A., E. Warren, and J. L. Westbrook (1994). Persistence of local legal culture: Twenty years of evidence from the federal bankruptcy courts. Harvard Journal of Law and Public Policy 17, 801.

White, M. J. (1987). Personal bankruptcy under the 1978 bankruptcy code: An economic analysis. Indiana Law Journal 63, 1.

White, M. J. and N. Zhu (2010). Saving your home in chapter 13 bankruptcy. Journal of Legal Studies 39, 33-61.

Yermack, D. (2014). Tailspotting: Identifying and profiting from ceo vacation trips. Journal of Financial Economics 113(2), 252-269. 
Panel A. District Courts in Sample

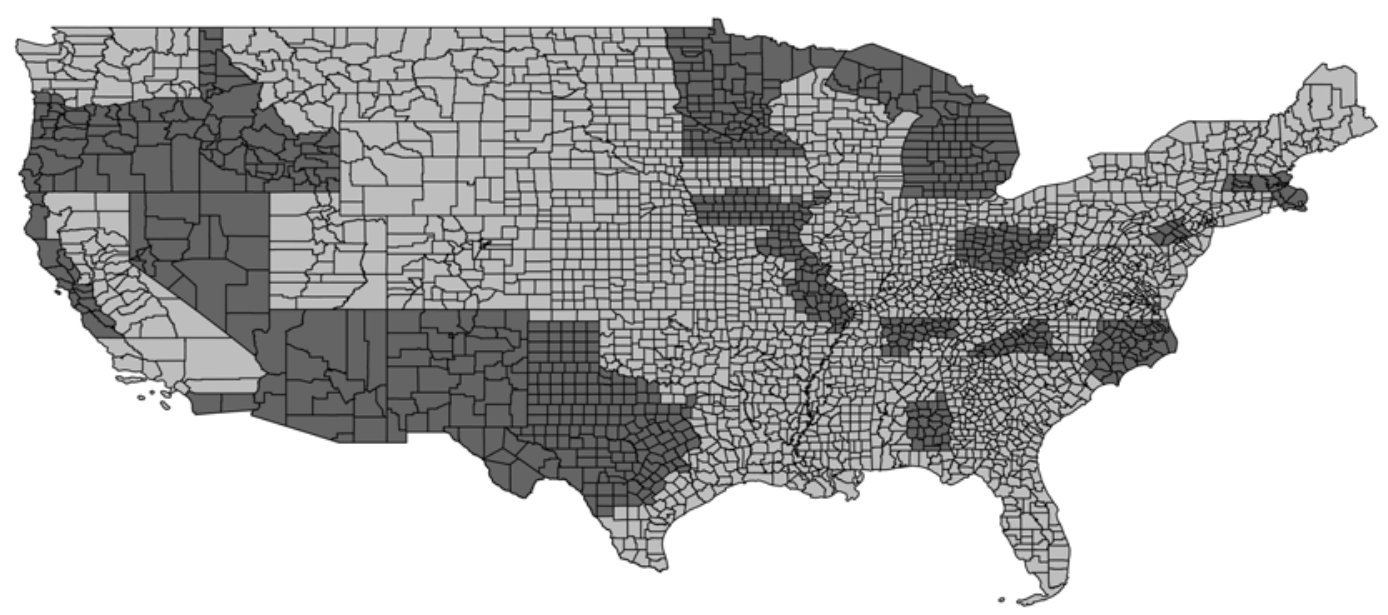

Panel B. District Courts in Sample that Allowed Cramdown

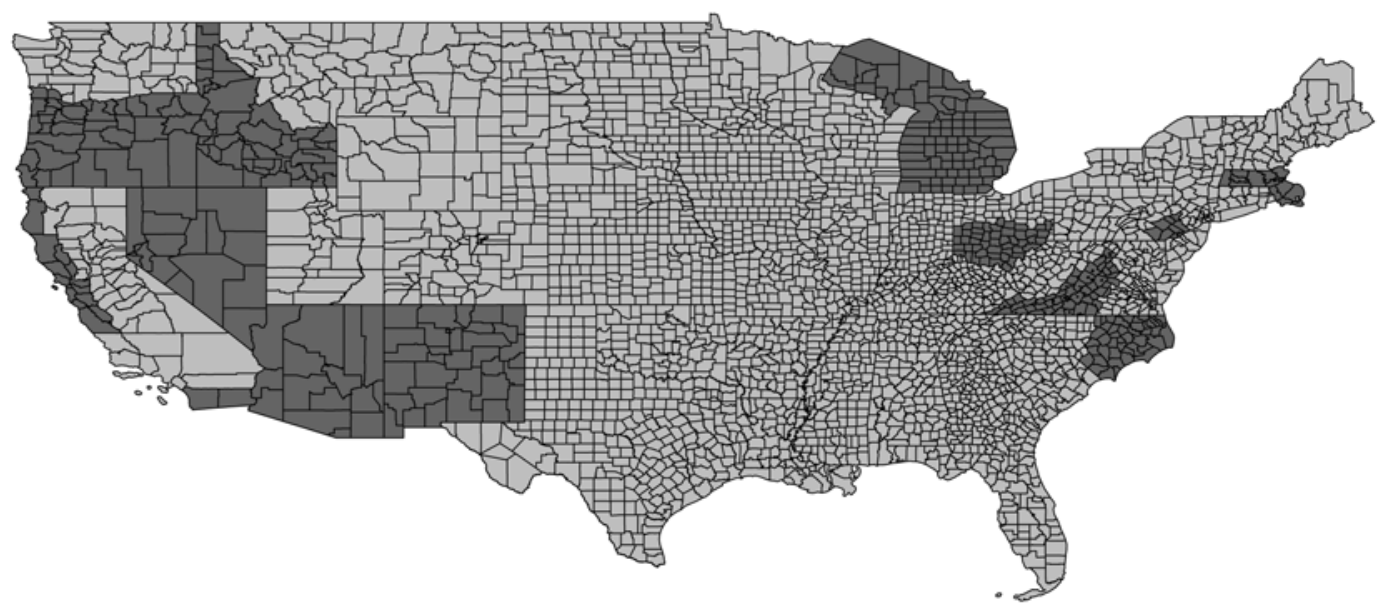

Figure 1. Bankruptcy district courts that allowed cramdown

These panels depict all courts in our sample and those courts that randomly assigned cases and allowed mortgage principal reduction. The dark gray shading in Panel A represents all the district courts in our sample, whereas in Panel B, the dark gray shading represents the courts in our sample that adopted mortgage cramdown between 1989 and 1993. 
Panel A. First stage without controls

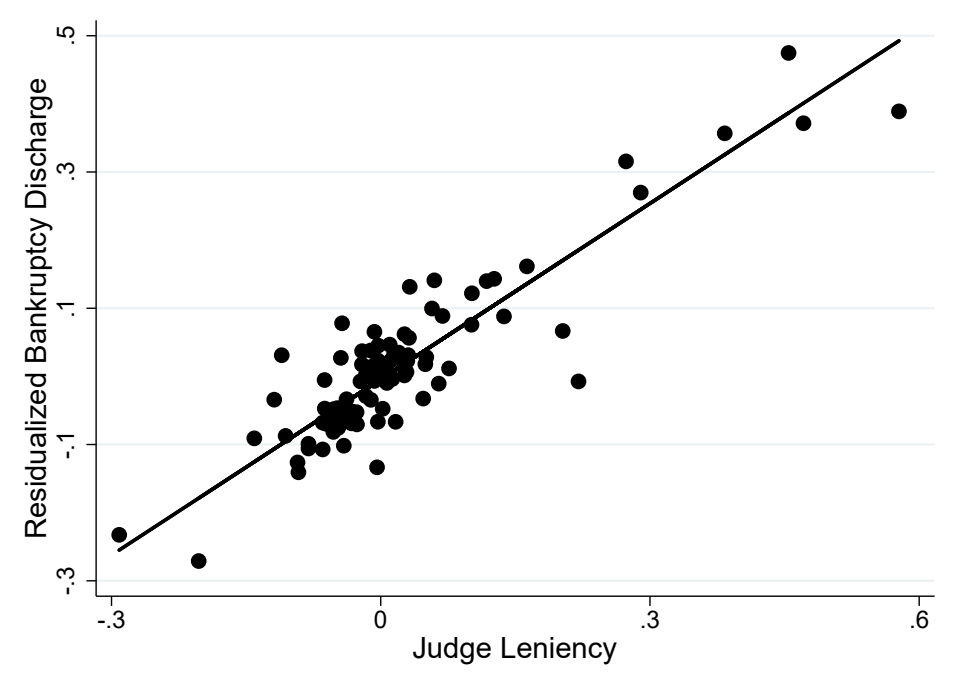

Panel B. First stage with controls

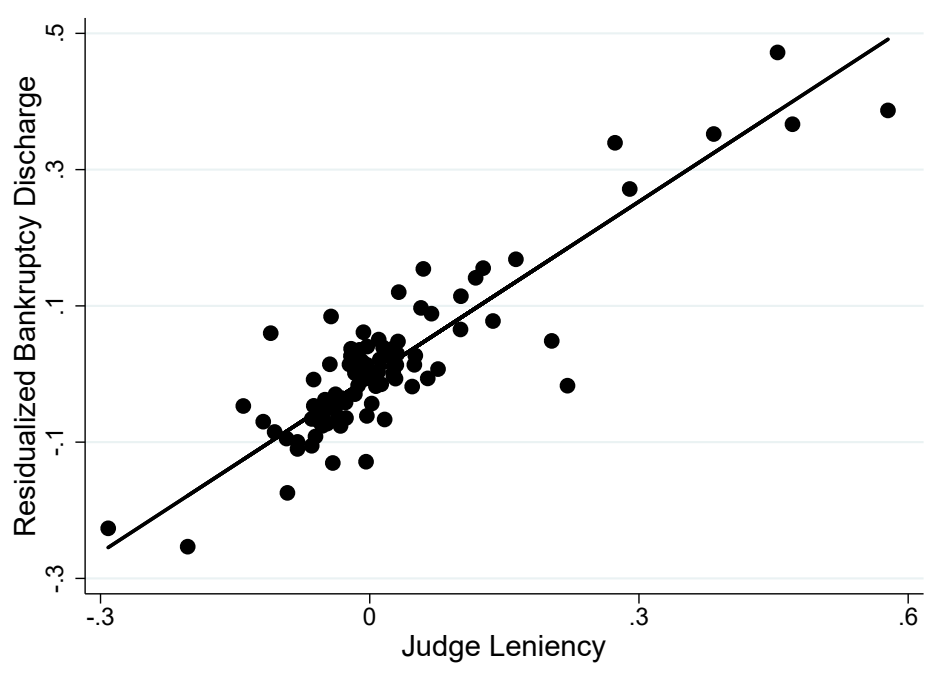

Figure 2. First stage: Relation between judge leniency and bankruptcy discharge These panels plot Chapter 13 discharge against the leave-one-out measure of judge leniency in cramdown courts. The sample consists of all first-time Chapter 13 filers between 1989 and 1993. To construct the binned scatterplot in Panel A, we regress an indicator variable for Chapter 13 discharge on office-by-month-of-filing fixed effects and calculate residuals. Subsequently, we calculate the mean residual in each judge-by-year bin. In Panel B, we follow the same procedure, but we include pre-treatment covariates at the filer and ZIP code levels. 


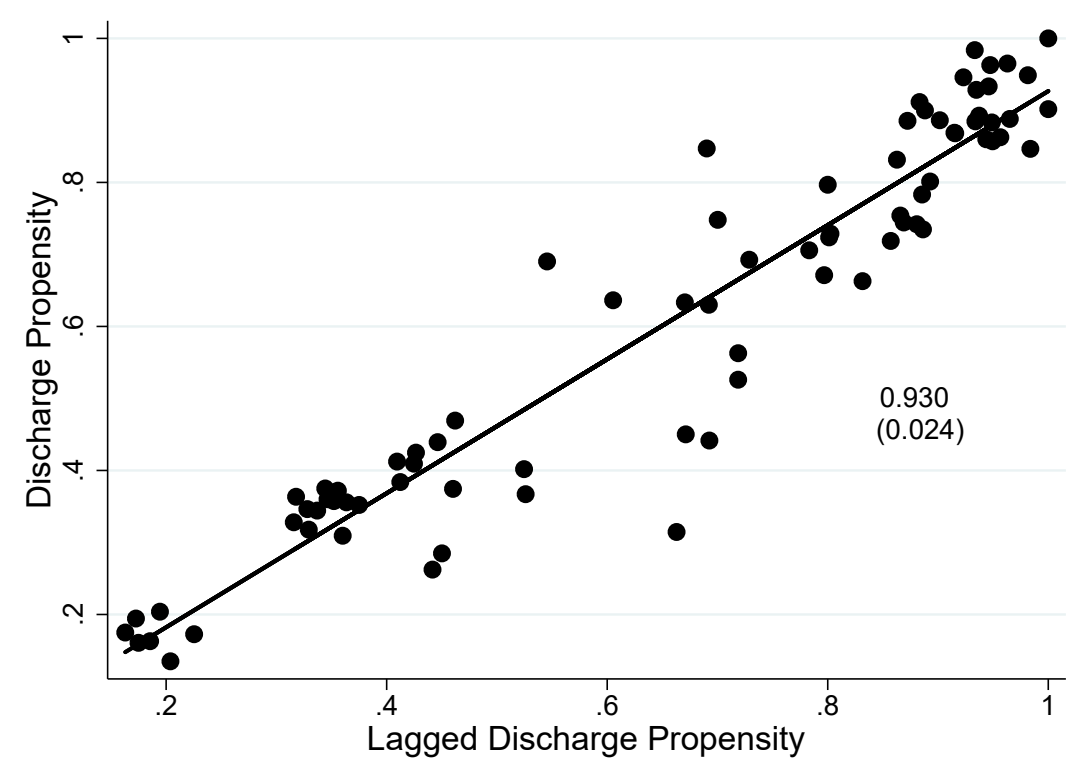

Figure 3. Persistence of Chapter 13 judge discharge rates

This figure shows the correlation between judge-specific Chapter 13 discharge rates in the current and lagged years. The sample consists of all first-time Chapter 13 filers between 1989 and 1993 in the offices that randomly assigned filings to judges, which allowed for mortgage cramdown in this period. 
Panel A. Home foreclosure

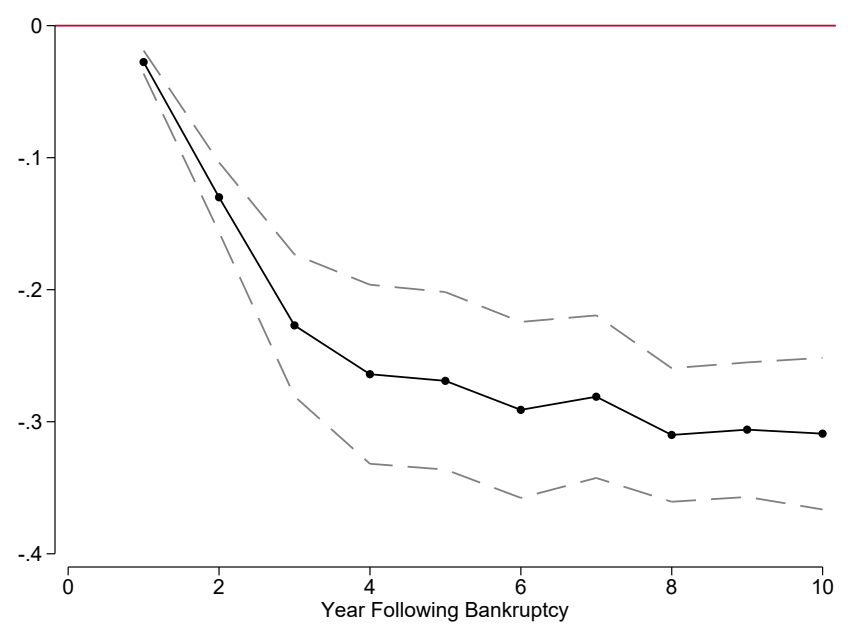

Panel B. Involuntary sale

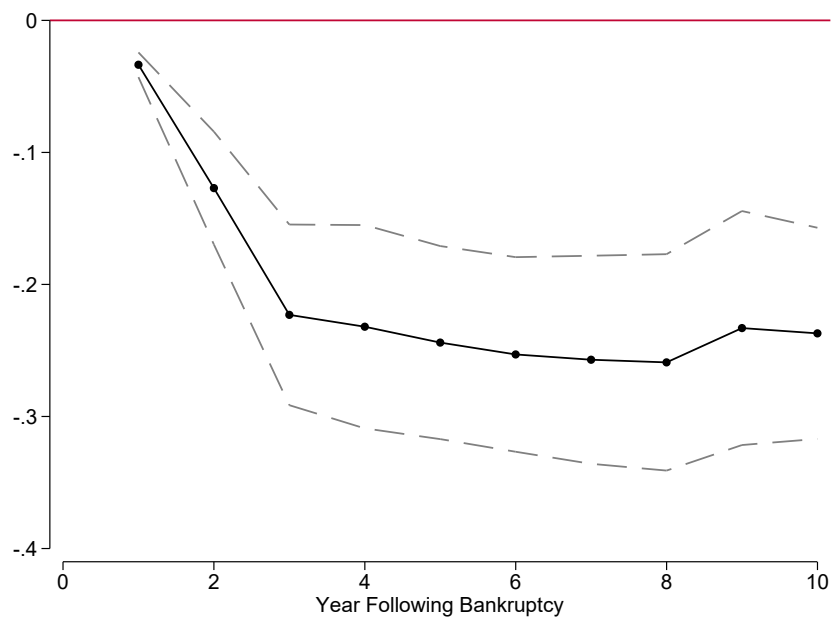

Figure 4. Home foreclosures and involuntary sales

These panels plot two-stage least squares estimates of the impact of Chapter 13 bankruptcy protection in courts that allowed mortgage cramdown on home foreclosures and involuntary sales. Home foreclosure is an indicator for a filer's home receiving a notice of default, transfer or sale, or having been transferred to a real estate owned in or before the indicated year. Involuntary sale is an indicator for when a home short sale is registered in or before the indicated year. The dashed lines represent $95 \%$ confidence intervals from standard errors clustered at the office-by-judge level. 
Panel A. Home foreclosure

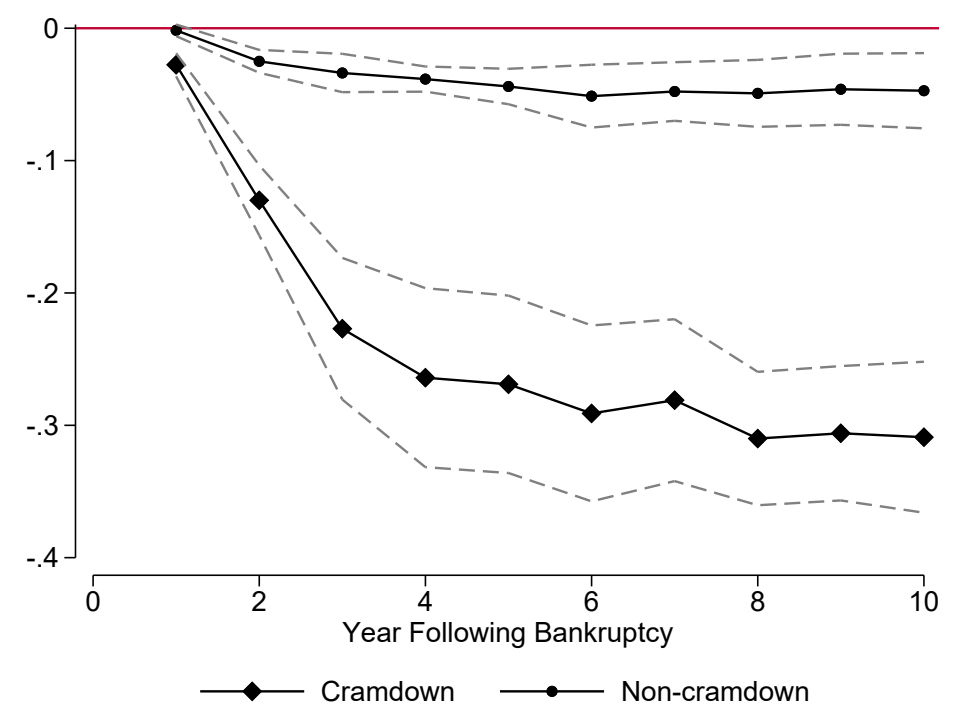

Panel B. Involuntary sale

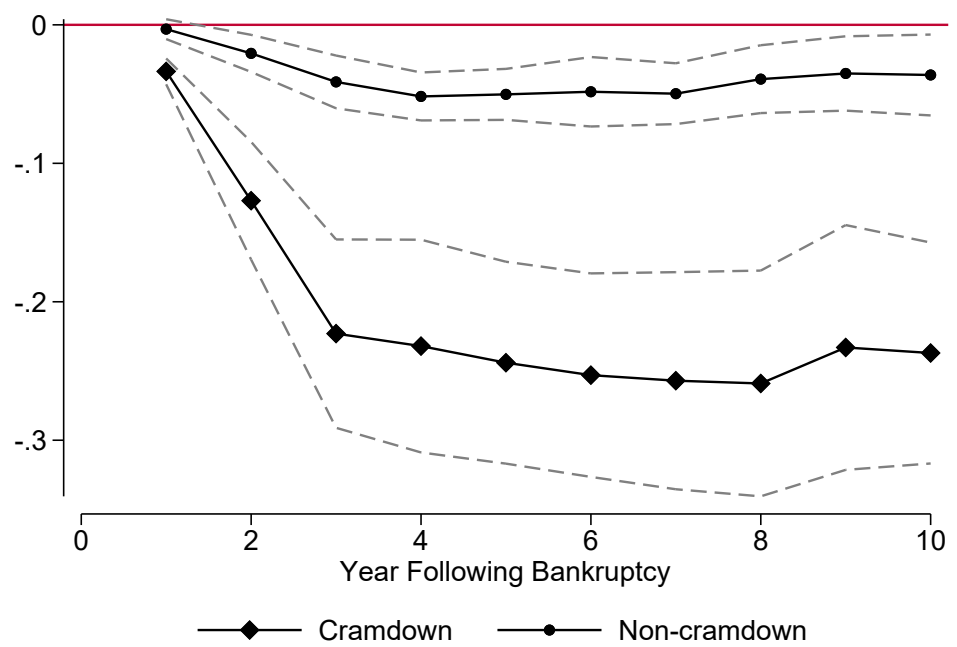

Figure 5. Cramdown versus non-cramdown courts

These panels plot the two-stage least squares estimates of the impact of Chapter 13 bankruptcy protection on home foreclosures and involuntary sales in cramdown and non-cramdown courts. Home foreclosure is an indicator for a filer's home receiving a notice of default, transfer or sale, or having been transferred to a real estate owned in or before the indicated year. Involuntary sale is an indicator for when a home short sale is registered in or before the indicated year. The dashed lines represent $95 \%$ confidence intervals from standard errors clustered at the office-by-judge level. 

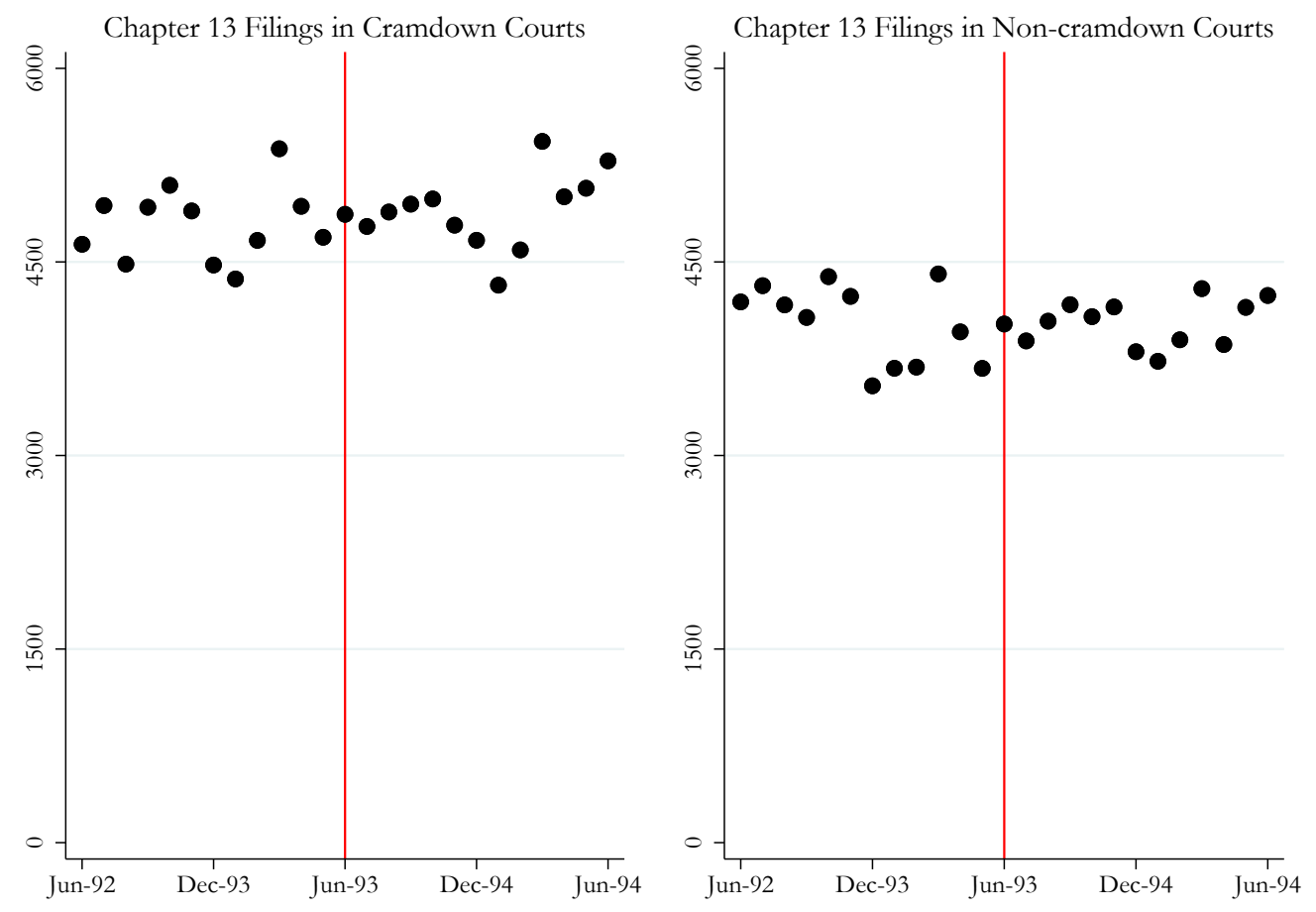

Figure 6. Time series of Chapter 13 bankruptcy filings around the Supreme Court decision in June 1993

The figure depicts the monthly number of Chapter 13 bankruptcy filings before and after the Supreme Court disallowed cramdown in June 1993. The sample consists of all Chapter 13 bankruptcy filings included in the PACER sample from June 1992 through June 1994. The sample consists of all Chapter 13 bankruptcy filings from June 1992 to June 1994 in the district courts for which we have docket data from PACER. Each dot in the panels represents the total count of Chapter 13 filings for that month. 
Table 1. Summary statistics

This table reports summary statistics for the sample consisting of first-time Chapter 13 filers between 1989 and 1993 in the offices that randomly assign filings to judges. The cramdown sample comprises the district courts that adopted mortgage cramdown in Chapter 13 between 1989 and 1993. The non-cramdown sample consists of those courts that did not allow mortgage cramdown during the same period. Age data come from the Lexis-Nexis (LN) public records and correspond to the individual's age at the time of filing. Gender data are from LN. ZIP-code-level pre-treatment characteristics are from the 1980 Centennial Census. Discharge is an indicator for receiving Chapter 13 bankruptcy protection.

\begin{tabular}{|c|c|c|c|c|c|c|c|}
\hline & \multirow{2}{*}{$\begin{array}{c}\text { Full sample } \\
\text { Mean } \\
(1)\end{array}$} & \multicolumn{3}{|c|}{ Cramdown } & \multicolumn{3}{|c|}{ Non-cramdown } \\
\hline & & $\begin{array}{c}\text { Mean } \\
(2)\end{array}$ & $\begin{array}{l}\mathrm{SD} \\
(3) \\
\end{array}$ & $\begin{array}{c}\text { Median } \\
(4)\end{array}$ & $\begin{array}{c}\text { Mean } \\
(5)\end{array}$ & $\begin{array}{r}\text { SD } \\
(6) \\
\end{array}$ & $\begin{array}{c}\text { Median } \\
(7)\end{array}$ \\
\hline Age & 41.65 & 42.20 & 10.68 & 41 & 41.24 & 10.82 & 40 \\
\hline Male & $78.40 \%$ & $81.62 \%$ & $38.73 \%$ & - & $75.73 \%$ & $42.87 \%$ & - \\
\hline Percentage white (ZIP code) & $40.10 \%$ & $40.45 \%$ & $33.69 \%$ & $37.82 \%$ & $39.85 \%$ & $34.79 \%$ & $33.88 \%$ \\
\hline Percentage single (ZIP code) & $9.28 \%$ & $9.36 \%$ & $8.81 \%$ & $6.71 \%$ & $9.22 \%$ & $8.85 \%$ & $7.78 \%$ \\
\hline Percentage college degree (ZIP code) & $7.40 \%$ & $7.86 \%$ & $8.93 \%$ & $4.86 \%$ & $7.06 \%$ & $8.21 \%$ & $4.86 \%$ \\
\hline Median income (ZIP code) & $22,744.86$ & $23,174.47$ & $20,674.57$ & $20,952.90$ & $22,427.39$ & $20,097.67$ & $21,072.44$ \\
\hline Number of cases & 14,517 & 6,100 & - & - & 8,417 & - & - \\
\hline Cases discharged & $65.55 \%$ & $61.54 \%$ & $48.65 \%$ & - & $68.55 \%$ & $46.43 \%$ & - \\
\hline
\end{tabular}


Table 2. Randomization test

This table presents reduced-form estimates testing the random assignment of filings to judges. The sample consists of all first-time Chapter 13 filers between 1989 and 1993 in the district courts that randomly assigned cases and allowed mortgage cramdown in this period. The estimates are from an OLS regression of judge leniency on the variables listed and office-by-month-of-filing fixed effects. Judge leniency, measured between 1989 and 1993, is the leave-one-out mean rate of granting bankruptcy protection for the assigned judge minus the leave-one-out mean rate of granting bankruptcy protection for the court in the same filing year. The $p$ value reported is for an $F$-test of the joint significance of the variables. Standard errors are clustered at the office-by-judge level. ${ }^{*} p<0.1 ;{ }^{* *} p<0.05 ;{ }^{* *} p<0.01$.

\begin{tabular}{lc}
\hline & $\begin{array}{c}\text { Leniency } \\
(1)\end{array}$ \\
\hline Age & -0.000118 \\
& $(7.82 \mathrm{e}-05)$ \\
Female & -0.00389 \\
& $(0.00263)$ \\
Percentage white (ZIP code) & 0.00549 \\
& $(0.00499)$ \\
Percentage single (ZIP code) & -0.0318 \\
& $(0.0215)$ \\
Percentage college degree (ZIP code) & -0.0483 \\
& $(0.0313)$ \\
ln (Median income) (ZIP code) & 0.000280 \\
& $(0.000687)$ \\
Joint F-test & \\
Office x Month FE & 0.3108 \\
Observations & Y \\
\hline
\end{tabular}


Table 3. First stage

This table reports the first-stage estimates. The sample consists of all firsttime Chapter 13 filers between 1989 and 1993 in the district courts that randomly assigned cases and allowed mortgage cramdown in this period. Judge leniency, measured between 1989 and 1993, is the leave-one-out mean rate of granting bankruptcy protection for the assigned judge minus the leave-one-out mean rate of granting bankruptcy protection for the court in the same filing year. All regressions include office-by-month-of-filing fixed effects. Standard errors are clustered at the office-by-judge level. ${ }^{*} p<0.1 ;{ }^{* *} p<0.05 ;{ }^{* * *} p<0.01$.

\begin{tabular}{|c|c|c|c|}
\hline & \multicolumn{3}{|c|}{ Discharge } \\
\hline & $(1)$ & $(2)$ & $(3)$ \\
\hline Leniency & $\begin{array}{c}0.894^{* * *} \\
(0.0311)\end{array}$ & $\begin{array}{c}0.895^{* * *} \\
(0.0316)\end{array}$ & $\begin{array}{c}0.891^{* * *} \\
(0.0315)\end{array}$ \\
\hline Age & & $\begin{array}{c}0.000891 \\
(0.000605)\end{array}$ & $\begin{array}{c}0.000952 \\
(0.000597)\end{array}$ \\
\hline Female & & $\begin{array}{c}-0.0468^{* * *} * \\
(0.0120)\end{array}$ & $\begin{array}{c}-0.0430^{* * *} \\
(0.0123)\end{array}$ \\
\hline Percentage white (ZIP code) & & & $\begin{array}{c}0.0772^{* *} \\
(0.0332)\end{array}$ \\
\hline Percentage single (ZIP code) & & & $\begin{array}{c}-0.276^{*} \\
(0.144)\end{array}$ \\
\hline Percentage college degree (ZIP code) & & & $\begin{array}{c}-0.0946 \\
(0.121)\end{array}$ \\
\hline ln (Median income) (ZIP code) & & & $\begin{array}{c}0.000597 \\
(0.00259)\end{array}$ \\
\hline Office x Month FE & Y & $\mathrm{Y}$ & $\mathrm{Y}$ \\
\hline Observations & 6,100 & 6,100 & 6,100 \\
\hline$R$-squared & 0.211 & 0.214 & 0.215 \\
\hline
\end{tabular}


Table 4. The effect of Chapter 13 in cramdown courts on homeowners' distress events This table reports two-stage least squares estimates of the impact of Chapter 13 bankruptcy protection in courts that allowed mortgage cramdown on homeowners' distress events. The sample consists of all first-time Chapter 13 filers between 1989 and 1993 in the district courts that randomly assigned cases and allowed mortgage cramdown in this period. Columns 1 and 2 report estimates for the three-year postfiling outcomes, with and without any controls, respectively. Columns 3 and 4 present the estimates for the five-year post-filing outcomes. Home foreclosure is an indicator for a filer's home receiving a notice of default, transfer or sale, or having been transferred to a real estate owned in or before the indicated year. Involuntary sale is an indicator for when a homeowner sells her property for less than the amount due on the mortgage in or before the indicated year. Controls include age and gender of the filer, and ZIP-code-level controls are the percentage of white population, percentage of single individuals, percentage of individuals with a college degree, and median log income. All regressions include office-by-month-of-filing fixed effects. Standard errors are clustered at the office-by-judge level. ${ }^{*} p<0.1 ;{ }^{*} p<0.05 ;{ }^{* *} p<0.01$.

Panel A

\begin{tabular}{|c|c|c|c|c|}
\hline & \multicolumn{4}{|c|}{ Foreclosure } \\
\hline & \multicolumn{2}{|c|}{$\begin{array}{c}\text { Year } 3 \text { post-filing } \\
(1)\end{array}$} & \multicolumn{2}{|c|}{ Year 5 post-filing } \\
\hline Discharge & $\begin{array}{c}-0.256^{* * *} \\
(0.0349)\end{array}$ & $\begin{array}{c}-0.263^{* * *} \\
(0.0324)\end{array}$ & $\begin{array}{c}-0.284^{* * *} \\
(0.0338)\end{array}$ & $\begin{array}{c}-0.292^{* * *} \\
(0.0307)\end{array}$ \\
\hline Control group mean & 0.2 & & & \\
\hline Controls & $\mathrm{N}$ & Y & $\mathrm{N}$ & Y \\
\hline Office x Month FE & Y & $\mathrm{Y}$ & $\mathrm{Y}$ & $\mathrm{Y}$ \\
\hline Observations & 6,100 & 6,100 & 6,100 & 6,100 \\
\hline$R$-squared & 0.088 & 0.090 & 0.094 & 0.097 \\
\hline \multicolumn{5}{|l|}{ Panel B } \\
\hline & \multicolumn{4}{|c|}{ Involuntary sale } \\
\hline & $\begin{array}{l}\text { Year } 3 p \\
(1)\end{array}$ & $\begin{array}{l}\text { st-filing } \\
\text { (2) }\end{array}$ & $\begin{array}{l}\text { Year } 5 \mathrm{p} \\
(3)\end{array}$ & $\begin{array}{l}\text { st-filing } \\
\text { (4) }\end{array}$ \\
\hline Discharge & $\begin{array}{c}-0.236^{* * *} \\
(0.0419)\end{array}$ & $\begin{array}{c}-0.244^{* * *} \\
(0.0386)\end{array}$ & $\begin{array}{c}-0.258^{* * *} \\
(0.0402)\end{array}$ & $\begin{array}{c}-0.267 * * * \\
(0.0371)\end{array}$ \\
\hline
\end{tabular}

Control group mean

0.181

0.191

Controls

Office x Month FE

$\begin{array}{ll}\mathrm{N} & \mathrm{Y} \\ \mathrm{Y} & \mathrm{Y}\end{array}$

Observations

$6,100 \quad 6,100$

$\begin{array}{ll}\mathrm{N} & \mathrm{Y} \\ \mathrm{Y} & \mathrm{Y}\end{array}$

$R$-squared

0.047

0.048

6,100

6,100

$0.035 \quad 0.036$ 
Table 5. The effect of Chapter 13 in cramdown courts on other outcomes This table reports two-stage least squares estimates of the impact of Chapter 13 bankruptcy protection in courts that allowed mortgage cramdown on other filers' outcomes. Each cell represents a separate regression. The sample consists of all first-time Chapter 13 filers between 1989 and 1993 in the district courts that randomly assigned cases and allowed mortgage cramdown in this period. New address is an indicator for the filer having at least one change of the principal address in or before the indicated year. Voluntary sale is an indicator for a property sale different from a home short sale in or before the indicated year. Moving to a better ZIP is an indicator for the filer moving for the first time post-filing to a ZIP code with a median income higher than the ZIP code at the time of bankruptcy filing. New property is an indicator for the filer buying a new property in or before the indicated year. Refinancing is an indicator for the filer refinancing a mortgage in or before the indicated year. Criminal filings is an indicator for the filer committing a traffic infraction or the filer being guilty of a misdemeanor or a felony in or before the indicated year. Mortality is an indicator for the filer having died in or before the indicated year. Controls are analogous to those in Table 4. All regressions include office-by-month-of-filing fixed effects. The mean of the control group is reported for those filers who did not receive Chapter 13 bankruptcy discharge. Standard errors are clustered at the office-by-judge level. ${ }^{*} p<0.1 ;{ }^{* *} p<0.05 ;{ }^{* * *} p$ $<0.01$.

\begin{tabular}{|c|c|c|c|c|}
\hline & \multicolumn{2}{|c|}{ Year 3 post-filing } & \multicolumn{2}{|c|}{ Year 5 post-filing } \\
\hline & $\begin{array}{c}\text { Control group } \\
\text { mean } \\
(1)\end{array}$ & $\begin{array}{c}\text { 2SLS Results } \\
(2)\end{array}$ & $\begin{array}{c}\text { Control group } \\
\text { mean } \\
(3)\end{array}$ & $\begin{array}{c}\text { 2SLS Results } \\
(4)\end{array}$ \\
\hline New address & 0.662 & $\begin{array}{c}-0.208^{* * *} \\
(0.0470)\end{array}$ & 0.769 & $\begin{array}{c}-0.195^{* * *} \\
(0.0487)\end{array}$ \\
\hline Voluntary sale & 0.157 & $\begin{array}{c}-0.0819^{* *} \\
(0.0348)\end{array}$ & 0.186 & $\begin{array}{c}-0.0868^{* *} \\
(0.0387)\end{array}$ \\
\hline Moving better ZIP & 0.122 & $\begin{array}{c}0.0550^{* *} \\
(0.0263)\end{array}$ & 0.125 & $\begin{array}{c}0.0606^{* *} \\
(0.0275)\end{array}$ \\
\hline New property & 0.074 & $\begin{array}{c}-0.0384 \\
(0.0347)\end{array}$ & 0.121 & $\begin{array}{c}-0.0117 \\
(0.0440)\end{array}$ \\
\hline Refinancing & 0.046 & $\begin{array}{c}-0.00724 \\
(0.0196)\end{array}$ & 0.107 & $\begin{array}{c}0.0595^{* * *} \\
(0.0187)\end{array}$ \\
\hline Criminal filings & 0.039 & $\begin{array}{c}-0.0301 * * * \\
(0.00879)\end{array}$ & 0.062 & $\begin{array}{c}-0.0492^{* * *} \\
(0.00815)\end{array}$ \\
\hline Mortality & 0.019 & $\begin{array}{c}0.00146 \\
(0.00800)\end{array}$ & 0.029 & $\begin{array}{l}0.00527 \\
(0.0210)\end{array}$ \\
\hline Controls & & Y & & Y \\
\hline Office x Month FE & & $\mathrm{Y}$ & & $\mathrm{Y}$ \\
\hline
\end{tabular}


Table 6. The effect of Chapter 13 in cramdown courts by filer characteristics This table reports two-stage least squares estimates of the impact of Chapter 13 bankruptcy protection in courts that allowed mortgage cramdown on homeowners' distress events. The sample consists of all first-time Chapter 13 filers between 1989 and 1993 in the district courts that randomly assigned cases and allowed mortgage cramdown in this period. The table reports estimates for the three-year post-filing outcomes with controls. Home foreclosure is an indicator for a filer's home receiving a notice of default, transfer or sale, or having been transferred to a real estate owned in or before the indicated year. Involuntary sale is an indicator for when a homeowner sells her property for less than the amount due on the mortgage in or before the indicated year. Controls are analogous to those in Table 4. All regressions include office-by-month-offiling fixed effects. Standard errors are clustered at the office-by-judge level. ${ }^{*} p<0.1$; ${ }^{* *} p<0.05 ; * * * p<0.01$.

Panel A

\begin{tabular}{|c|c|c|c|c|c|c|}
\hline \multicolumn{7}{|c|}{ Foreclosure } \\
\hline \multicolumn{2}{|c|}{ Gender } & \multicolumn{3}{|c|}{$\begin{array}{l}\text { Year } 3 \text { post-filing } \\
\text { Age at filing }\end{array}$} & \multicolumn{2}{|c|}{ Property type } \\
\hline $\begin{array}{l}\text { Male } \\
(1)\end{array}$ & $\begin{array}{c}\text { Female } \\
(2)\end{array}$ & $\begin{array}{c}\text { lower } 35 \\
(3)\end{array}$ & $\begin{array}{c}35-50 \\
(4)\end{array}$ & $\begin{array}{l}50 \text { and up } \\
(5)\end{array}$ & $\begin{array}{c}\text { Single-family } \\
\text { (6) }\end{array}$ & $\begin{array}{l}\text { Multi-family } \\
(7)\end{array}$ \\
\hline $\begin{array}{c}-0.248^{* * *} \\
(0.0292)\end{array}$ & $\begin{array}{c}-0.361^{* * *} \\
(0.132)\end{array}$ & $\begin{array}{c}-0.266^{* * *} \\
(0.0466)\end{array}$ & $\begin{array}{c}-0.267^{* * *} \\
(0.0318)\end{array}$ & $\begin{array}{c}-0.247^{* * *} \\
(0.0595)\end{array}$ & $\begin{array}{c}-0.276^{* * *} \\
(0.0339)\end{array}$ & $\begin{array}{c}-0.195^{* * *} \\
(0.0690)\end{array}$ \\
\hline \multicolumn{2}{|c|}{0.385} & \multicolumn{3}{|c|}{0.818} & \multicolumn{2}{|c|}{0.264} \\
\hline \multicolumn{2}{|c|}{ Y } & \multicolumn{3}{|c|}{$\mathrm{Y}$} & \multicolumn{2}{|c|}{ Y } \\
\hline \multicolumn{2}{|c|}{$\mathrm{Y}$} & \multicolumn{3}{|c|}{ Y } & \multicolumn{2}{|c|}{$\mathrm{Y}$} \\
\hline \multicolumn{2}{|c|}{6,100} & \multicolumn{3}{|c|}{6,100} & \multicolumn{2}{|c|}{5,641} \\
\hline
\end{tabular}

Observations

Involuntary sale

\begin{tabular}{|c|c|c|c|c|c|c|c|}
\hline & \multicolumn{7}{|c|}{ Involuntary sale } \\
\hline & \multicolumn{2}{|c|}{ Gender } & \multicolumn{3}{|c|}{$\begin{array}{l}\text { Year } 3 \text { post-filing } \\
\text { Age at filing }\end{array}$} & \multicolumn{2}{|c|}{ Property type } \\
\hline & $\begin{array}{l}\text { Male } \\
(1)\end{array}$ & $\begin{array}{c}\text { Female } \\
(2)\end{array}$ & $\begin{array}{c}\text { lower } 35 \\
(3)\end{array}$ & $\begin{array}{c}35-50 \\
(4)\end{array}$ & $\begin{array}{c}50 \text { and up } \\
\text { (5) }\end{array}$ & $\begin{array}{c}\text { Single-family } \\
(6)\end{array}$ & $\begin{array}{c}\text { Multi-family } \\
(7)\end{array}$ \\
\hline Discharge & $\begin{array}{c}-0.217^{* * *} \\
(0.0332)\end{array}$ & $\begin{array}{c}-0.410^{* * *} \\
(0.118)\end{array}$ & $\begin{array}{c}-0.272^{* * *} \\
(0.0319)\end{array}$ & $\begin{array}{c}-0.245^{* * *} \\
(0.0461)\end{array}$ & $\begin{array}{c}-0.192^{* *} \\
(0.0786)\end{array}$ & $\begin{array}{c}-0.257^{* * *} \\
(0.0414)\end{array}$ & $\begin{array}{l}-0.144^{*} \\
(0.0839)\end{array}$ \\
\hline$p$-value & \multicolumn{2}{|c|}{0.047} & \multicolumn{3}{|c|}{0.553} & \multicolumn{2}{|c|}{0.183} \\
\hline Controls & \multicolumn{2}{|c|}{$\mathrm{Y}$} & \multicolumn{3}{|c|}{$\mathrm{Y}$} & \multicolumn{2}{|c|}{ Y } \\
\hline Office $x$ Month FE & \multicolumn{2}{|c|}{$\mathrm{Y}$} & \multicolumn{3}{|c|}{$\mathrm{Y}$} & \multicolumn{2}{|c|}{$\mathrm{Y}$} \\
\hline Observations & \multicolumn{2}{|c|}{6,100} & \multicolumn{3}{|c|}{6,100} & \multicolumn{2}{|c|}{5,641} \\
\hline
\end{tabular}

Panel B 
Table 7. Cramdown and non-cramdown in Chapter 13 bankruptcy This table reports two-stage least squares estimates of the impact of Chapter 13 bankruptcy protection on homeowners' distress events for courts that did and did not allow cramdown. The sample consists of all first-time Chapter 13 filers between 1989 and 1993 in the district courts that randomly assigned cases in this period. Discharge is an indicator for a case being filed in a court that allowed cramdown at the time of the filing. Non-cramdown is an indicator for a case being filed in a court that prohibited cramdown at the time of the filing. Outcome variables and controls are analogous to those in Table 4. All regressions include office-by-month-of-filing fixed effects. Standard errors are clustered at the office-by-judge level. ${ }^{*} p<0.1 ;{ }^{* *} p<0.05$; ${ }^{* * *} p<0.01$.

\begin{tabular}{|c|c|c|c|c|}
\hline \multirow{3}{*}{ Panel A } & \multicolumn{4}{|c|}{ Foreclosure } \\
\hline & \multicolumn{2}{|c|}{ Year 3 post-filing } & \multicolumn{2}{|c|}{ Year 5 post-filing } \\
\hline & $(1)$ & $(2)$ & $(3)$ & $(4)$ \\
\hline Discharge $\mathrm{x}$ Cramdown & $-0.264^{* * *}$ & $-0.267 * * *$ & $-0.291^{* * *}$ & $-0.294^{* * *}$ \\
\hline & $(0.0345)$ & $(0.0327)$ & $(0.0339)$ & $(0.0316)$ \\
\hline Discharge x Non-cramdown & $-0.0384^{* * *}$ & $-0.0392^{* * *}$ & $-0.0513^{* * *}$ & $-0.0526 * * *$ \\
\hline & $(0.00485)$ & $(0.00497)$ & $(0.0121)$ & $(0.0118)$ \\
\hline$p$-value & 0.000 & 0.000 & 0.000 & 0.000 \\
\hline Controls & $\mathrm{N}$ & $\mathrm{Y}$ & $\mathrm{N}$ & $\mathrm{Y}$ \\
\hline Office x Month FE & $\mathrm{Y}$ & $\mathrm{Y}$ & $\mathrm{Y}$ & $\mathrm{Y}$ \\
\hline Observations & 14,517 & 14,517 & 14,517 & 14,517 \\
\hline$R$-squared & 0.070 & 0.071 & 0.074 & 0.075 \\
\hline \multicolumn{5}{|l|}{ Panel B } \\
\hline & \multicolumn{4}{|c|}{ Involuntary sale } \\
\hline & \multicolumn{2}{|c|}{ Year 3 post-filing } & \multicolumn{2}{|c|}{ Year 5 post-filing } \\
\hline & $(1)$ & $(2)$ & $(3)$ & $(4)$ \\
\hline Discharge $\mathrm{x}$ Cramdown & $-0.232^{* * *}$ & $-0.234^{* * *}$ & $-0.253^{* * *}$ & $-0.256^{* * *}$ \\
\hline & $(0.0392)$ & $(0.0377)$ & $(0.0375)$ & $(0.0365)$ \\
\hline Discharge $\mathrm{x}$ Non-cramdown & $-0.0517^{* * *}$ & $-0.0522^{* * *}$ & $-0.0483 * * *$ & $-0.0483^{* * *}$ \\
\hline & $(0.00884)$ & $(0.00894)$ & $(0.0128)$ & $(0.0126)$ \\
\hline$p$-value & 0.000 & 0.000 & 0.000 & 0.000 \\
\hline Controls & $\mathrm{N}$ & $\mathrm{Y}$ & $\mathrm{N}$ & $\mathrm{Y}$ \\
\hline Office x Month FE & Y & Y & $\mathrm{Y}$ & Y \\
\hline Observations & 14,517 & 14,517 & 14,517 & 14,517 \\
\hline$R$-squared & 0.039 & 0.039 & 0.027 & 0.028 \\
\hline
\end{tabular}


Table 8 . The effect of Chapter 13 bankruptcy protection within states with both cramdown and non-cramdown courts

This table reports two-stage least squares estimates of the impact of Chapter 13 bankruptcy protection on homeowners' distress events within states with both cramdown and non-cramdown courts. The sample consists of all first-time Chapter 13 filers between 1989 and 1993 in the district courts that randomly assigned cases in this period. Discharge is an indicator for a case being filed in a court that allowed cramdown at the time of the filing. Non-cramdown is an indicator for a case being filed in a court that prohibited cramdown at the time of the filing. Outcome variables and controls are analogous to those in Table 4. All regressions include office-by-month-of-filing fixed effects. Standard errors are clustered at the office-by-judge level. ${ }^{*} p<0.1 ;{ }^{*} p<0.05$; $* * * p<0.01$.

Panel A

\begin{tabular}{|c|c|c|c|c|}
\hline & \multicolumn{4}{|c|}{ Foreclosure } \\
\hline & \multicolumn{2}{|c|}{ Year 3 post-filing } & \multicolumn{2}{|c|}{ Year 5 post-filing } \\
\hline & $(1)$ & $(2)$ & $(3)$ & $(4)$ \\
\hline Discharge x Cramdown & $\begin{array}{c}-0.264^{* * *} \\
(0.0346)\end{array}$ & $\begin{array}{c}-0.268^{* * *} \\
(0.0320)\end{array}$ & $\begin{array}{c}-0.291^{* * *} \\
(0.0340)\end{array}$ & $\begin{array}{c}-0.296^{* * *} \\
(0.0309)\end{array}$ \\
\hline Discharge $\mathrm{x}$ Non-cramdown & $\begin{array}{c}-0.0405^{* * *} * \\
(0.00436)\end{array}$ & $\begin{array}{c}-0.0417^{* * *} \\
(0.00447)\end{array}$ & $\begin{array}{c}-0.0562^{* * *} \\
(0.0150)\end{array}$ & $\begin{array}{c}-0.0580^{* * *} \\
(0.0143)\end{array}$ \\
\hline$p$-value & 0.000 & 0.000 & 0.000 & 0.000 \\
\hline Controls & $\mathrm{N}$ & $\mathrm{Y}$ & $\mathrm{N}$ & $\mathrm{Y}$ \\
\hline Office x Month FE & $\mathrm{Y}$ & $\mathrm{Y}$ & $\mathrm{Y}$ & $\mathrm{Y}$ \\
\hline Observations & 9,475 & 9,475 & 9,475 & 9,475 \\
\hline$R$-squared & 0.073 & 0.073 & 0.079 & 0.080 \\
\hline \multicolumn{5}{|l|}{ Panel B } \\
\hline & \multicolumn{4}{|c|}{ Involuntary sale } \\
\hline & \multicolumn{2}{|c|}{$\begin{array}{l}\text { Year } 3 \text { post-filing } \\
(1)\end{array}$} & \multicolumn{2}{|c|}{ Year 5 post-filing } \\
\hline Discharge x Cramdown & $\begin{array}{c}-0.232^{* * *} \\
(0.0393)\end{array}$ & $\begin{array}{c}-0.232^{* * *} \\
(0.0393)\end{array}$ & $\begin{array}{c}-0.253^{* * *} \\
(0.0376)\end{array}$ & $\begin{array}{c}-0.257^{* * *} \\
(0.0362)\end{array}$ \\
\hline Discharge $\mathrm{x}$ Non-cramdown & $\begin{array}{c}-0.0545^{* * *} \\
(0.00851)\end{array}$ & $\begin{array}{c}-0.0545^{* * *} \\
(0.00851)\end{array}$ & $\begin{array}{c}-0.0523^{* * *} \\
(0.0155)\end{array}$ & $\begin{array}{c}-0.0521^{* * *} \\
(0.0152)\end{array}$ \\
\hline$p$-value & 0.000 & 0.000 & 0.000 & 0.000 \\
\hline Controls & $\mathrm{N}$ & $\mathrm{Y}$ & $\mathrm{N}$ & $\mathrm{Y}$ \\
\hline Office x Month FE & $\mathrm{Y}$ & $\mathrm{Y}$ & Y & $\mathrm{Y}$ \\
\hline Observations & 9,475 & 9,475 & 9,475 & 9,475 \\
\hline$R$-squared & 0.045 & 0.044 & 0.033 & 0.033 \\
\hline
\end{tabular}


Table 9. Complier characteristics: Cramdown and non-cramdown This table presents the characteristics of compliers. Column (1) reports the distribution of the sample by gender and age, $P(X=x)$. Column (2) shows the first-stage estimates for each gender and age group. Column (3) reports the distribution of compliers by gender and age, $P\left(X=x \mid I_{1}>I_{0}\right)$, calculated as the first-stage estimate for the gender minus age group times the sample share, divided by the overall first-stage estimate. Column (4) shows the relative likelihood of a filer belonging to a particular gender and age group, in the complier group compared with the sample. Panel A reports the complier characteristics for the cramdown sample, whereas Panel B presents the complier characteristics for the non-cramdown sample.

Panel A

$$
\begin{array}{ccc}
P(X=x) \quad \text { First stage } & P\left(X=x \mid I_{1}>I_{0}\right) & P\left(X=x \mid I_{1}>I_{0}\right) \\
& & \\
& & P(X=x)
\end{array}
$$

(1)

(2)

(3)

\begin{tabular}{|c|c|c|c|c|}
\hline \multicolumn{5}{|l|}{ Men } \\
\hline Age $<35$ & 0.207 & 0.998 & 0.231 & 1.116 \\
\hline $35<=$ Age $<=50$ & 0.433 & 0.886 & 0.430 & 0.991 \\
\hline Age $>50$ & 0.174 & 0.972 & 0.189 & 1.087 \\
\hline \multicolumn{5}{|l|}{ Women } \\
\hline Age $<35$ & 0.043 & 1.003 & 0.048 & 1.122 \\
\hline $35<=$ Age $<=50$ & 0.092 & 0.641 & 0.066 & 0.717 \\
\hline Age $>50$ & 0.051 & 0.858 & 0.049 & 0.960 \\
\hline Overall & 1.000 & 0.894 & 1.000 & 1.000 \\
\hline \multicolumn{5}{|l|}{ Panel B } \\
\hline & $P(X=x)$ & First stage & $P\left(X=x \mid I_{1}>I_{0}\right)$ & $\begin{array}{c}P\left(X=x \mid I_{1}>I_{0}\right) \\
\quad / P(X=x)\end{array}$ \\
\hline & $(1)$ & $(2)$ & $(3)$ & $(4)$ \\
\hline \multicolumn{5}{|l|}{ Men } \\
\hline Age $<35$ & 0.229 & 0.931 & 0.239 & 1.041 \\
\hline $35<=$ Age $<=50$ & 0.377 & 0.991 & 0.418 & 1.109 \\
\hline Age $>50$ & 0.151 & 0.975 & 0.165 & 1.091 \\
\hline \multicolumn{5}{|l|}{ Women } \\
\hline Age $<35$ & 0.064 & 1.127 & 0.081 & 1.261 \\
\hline $35<=$ Age $<=50$ & 0.122 & 0.916 & 0.125 & 1.025 \\
\hline Age $>50$ & 0.057 & 0.763 & 0.049 & 0.853 \\
\hline Overall & 1.000 & 0.894 & 1.000 & 1.000 \\
\hline
\end{tabular}

(4) 


\section{Internet Appendix}

Panel A. Cramdown courts

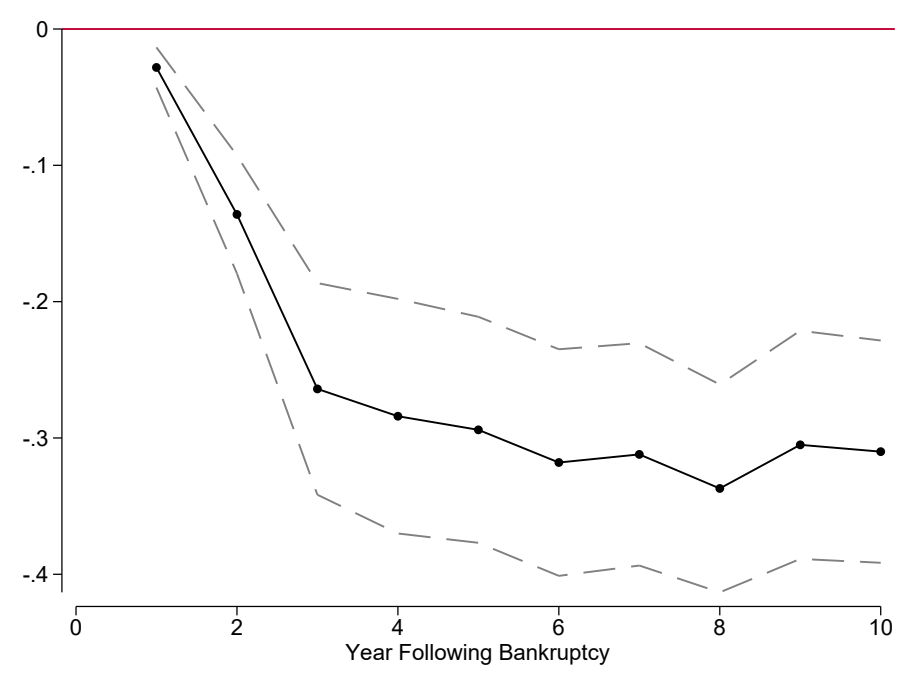

Panel B. Non-cramdown courts

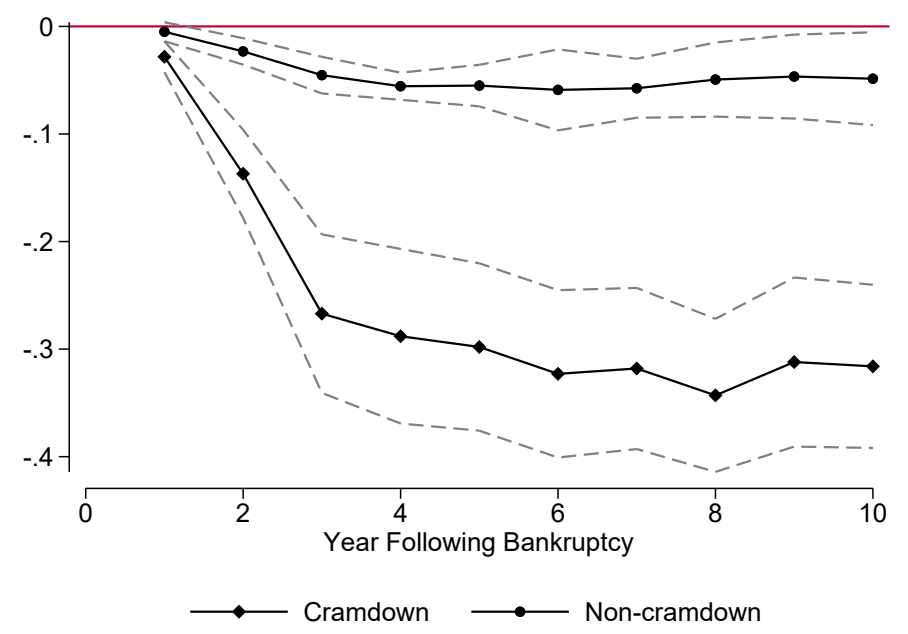

Figure IA.1. Any distress event in cramdown and non-cramdown courts These figures plot two-stage least squares estimates of the impact of Chapter 13 bankruptcy protection on any distress event in cramdown and non-cramdown courts. Any distress event is similar to the foreclosure indicator described in the Figure 4 variable plus other events, such as real-estate-owned liquidation (REO) in or before the indicated year. Panel A depicts the estimates for any distress events in courts that allowed cramdown in Chapter 13, whereas Panel B presents the estimates for noncramdown courts. The dashed lines represent $95 \%$ confidence intervals from standard errors clustered at the office-by-judge level. 


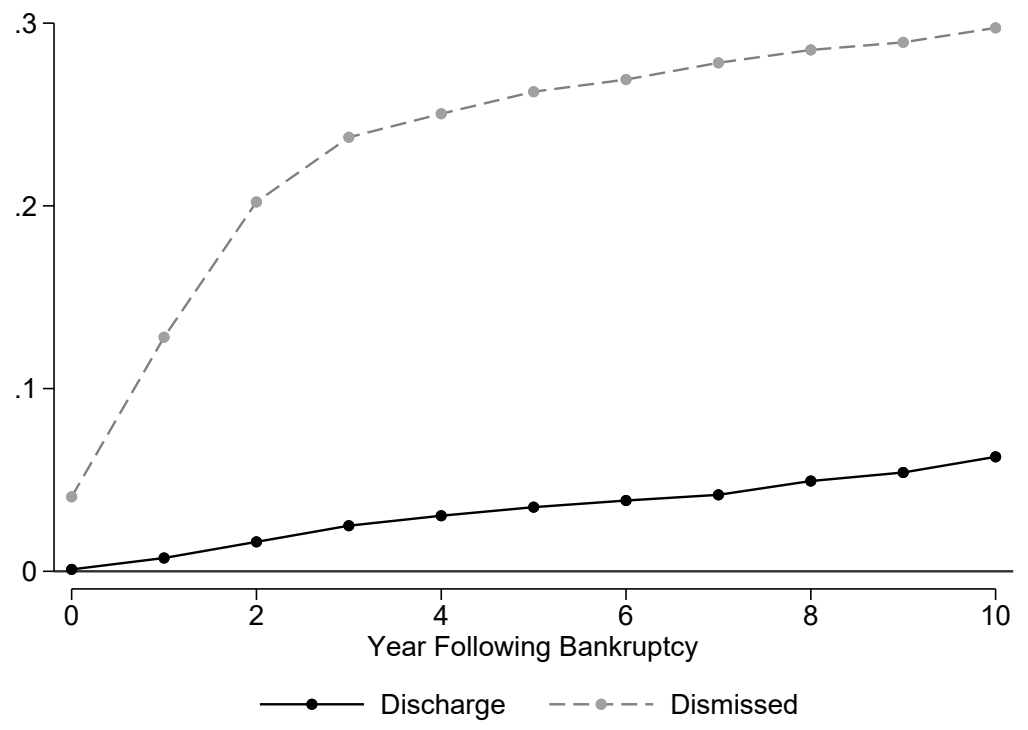

Figure IA.2. Home Foreclosure of discharged vs. dismissed filers in cramdown courts These figure plots average home foreclosure for granted and dismissed Chapter 13 bankruptcy filers in courts in which cramdown was allowed. Home foreclosure is an indicator for a filer's home receiving a notice of default, transfer or sale, or having been transferred to a real estate owned in or before the indicated year. 
Table IA.1. The effect of Chapter 13 in cramdown courts on foreclosure in recession periods

This table reports two-stage least squares estimates of the impact of Chapter 13 bankruptcy protection in courts that allowed mortgage cramdown on foreclosures during recession. The sample consists of all first-time Chapter 13 filers between 1989 and 1993 in the district courts that randomly assigned cases in this period. Recession is an indicator variable for a case being filed between July 1990 and March 1991 (NBER). Outcome variables and controls are analogous to those in Table 4. All regressions include office-by-month-of-filing fixed effects. Standard errors are clustered at office-by-judge level. ${ }^{*} p<0.1 ;{ }^{* *} p<0.05 ;{ }^{* * *} p<0.01$.

\begin{tabular}{|c|c|c|c|c|}
\hline & \multicolumn{4}{|c|}{ Foreclosure } \\
\hline & \multicolumn{2}{|c|}{ Year 3 post-filing } & \multicolumn{2}{|c|}{ Year 5 post-filing } \\
\hline & $\begin{array}{c}\text { Recession } \\
(1)\end{array}$ & $\begin{array}{c}\text { Non-recession } \\
(2)\end{array}$ & $\begin{array}{c}\text { Recession } \\
(3)\end{array}$ & $\begin{array}{c}\text { Non-recession } \\
(4)\end{array}$ \\
\hline Discharge & $\begin{array}{c}-0.287^{* * *} \\
(0.0600)\end{array}$ & $\begin{array}{c}-0.262^{* * *} \\
(0.0403)\end{array}$ & $\begin{array}{c}-0.353^{* * *} \\
(0.0883)\end{array}$ & $\begin{array}{c}-0.285^{* * *} \\
(0.0437)\end{array}$ \\
\hline $\mathrm{p}$-value & & 0.736 & & 0.543 \\
\hline Controls & & $\mathrm{Y}$ & & $\mathrm{Y}$ \\
\hline Office x Month FE & & $\mathrm{Y}$ & & $\mathrm{Y}$ \\
\hline Observations & & 6,100 & & 6,100 \\
\hline$R$-squared & & 0.090 & & 0.095 \\
\hline
\end{tabular}


Table IA.2. The effect of Chapter 13 in cramdown courts on foreclosure based on states' recourse status and homestead exemption generosity

This table reports two-stage least squares estimates of the impact of Chapter 13 bankruptcy protection in courts that allowed mortgage cramdown on foreclosures based on a state's recourse status and homestead exemption generosity. The sample consists of all first-time Chapter 13 filers between 1989 and 1993 in the district courts that randomly assigned cases in this period. Recourse is an indicator equal to one if the case is filed in a recourse state. Above median equals is an indicator equal to one if the case is filed in a state with homestead exemption above the median. Homestead exemption median is computed using only the states in our sample and the 1996 homestead exemptions. Outcome variables and controls are analogous to those in Table 4. All regressions include office-by-month-of-filing fixed effects. Standard errors are clustered at office-by-judge level. ${ }^{*} p<0.1 ;{ }^{* *} p<0.05$; ${ }^{* * *} p<0.01$.

Panel A

\begin{tabular}{|c|c|c|c|c|}
\hline & \multicolumn{4}{|c|}{ Foreclosure } \\
\hline & \multicolumn{2}{|c|}{ Year 3 post-filing } & \multicolumn{2}{|c|}{ Year 5 post-filing } \\
\hline & $\begin{array}{l}\text { Recourse } \\
(1)\end{array}$ & $\begin{array}{c}\text { Non-Recourse } \\
(2)\end{array}$ & $\begin{array}{c}\text { Recourse } \\
\quad(3) \\
\end{array}$ & $\begin{array}{c}\text { Non-Recourse } \\
(4)\end{array}$ \\
\hline Discharge & $\begin{array}{c}-0.194^{* *} \\
(0.0965)\end{array}$ & $\begin{array}{c}-0.291^{* * *} \\
(0.0276)\end{array}$ & $\begin{array}{c}-0.236^{* *} \\
(0.113)\end{array}$ & $\begin{array}{c}-0.317^{* * *} \\
(0.0254)\end{array}$ \\
\hline$p$-value & & 27 & & \\
\hline Controls & & V & & \\
\hline Office x Month FE & & & & \\
\hline Observations & & & & \\
\hline$R$-squared & & & & \\
\hline \multicolumn{5}{|l|}{ Panel B } \\
\hline & \multicolumn{4}{|c|}{ Foreclosure } \\
\hline & \multicolumn{2}{|c|}{ Year 3 post-filing } & \multicolumn{2}{|c|}{ Year 5 post-filing } \\
\hline & \multicolumn{4}{|c|}{ Homestead exemption } \\
\hline & $\begin{array}{c}\text { Above mediar } \\
(1)\end{array}$ & $\begin{array}{c}\text { Below median } \\
(2) \\
\end{array}$ & $\begin{array}{c}\text { Above median } \\
(3)\end{array}$ & $\begin{array}{c}\text { Below median } \\
(4)\end{array}$ \\
\hline Discharge & $\begin{array}{c}-0.349 * * \\
(0.171)\end{array}$ & $\begin{array}{c}-0.263^{* * *} \\
(0.0323)\end{array}$ & $\begin{array}{c}-0.386^{* *} \\
(0.176)\end{array}$ & $\begin{array}{c}-0.292^{* * *} \\
(0.0307)\end{array}$ \\
\hline$p$-value & \multicolumn{2}{|c|}{0.627} & \multicolumn{2}{|c|}{0.598} \\
\hline Controls & \multicolumn{2}{|c|}{$\mathrm{Y}$} & \multicolumn{2}{|c|}{$\mathrm{Y}$} \\
\hline Office x Month FE & \multicolumn{2}{|c|}{ Y } & \multicolumn{2}{|c|}{ Y } \\
\hline Observations & \multicolumn{2}{|c|}{6,100} & \multicolumn{2}{|c|}{6,100} \\
\hline$R$-squared & \multicolumn{2}{|c|}{0.089} & \multicolumn{2}{|c|}{0.095} \\
\hline
\end{tabular}


Table IA.3. The effect of cramdown on filers' observable covariates and bankruptcy Chapter composition

This table reports the difference-in-differences estimates of the effect of cramdown on homeowners' observable covariates and districts' bankruptcy type composition. Cramdown is an indicator equal to one if the district allowed cramdown in month $t$ and zero otherwise. In Panel A, the sample consists of all first-time Chapter 13 filers between 1989 and 1993 in the district courts that randomly assigned cases in this period. The outcome variables are a dummy equal to one if the filer is female and the age at filing, respectively. In Panel B, the sample period is between 1988 and 1995. The outcome variable is the share of Chapter 7 cases relative to the total bankruptcy cases (Chapter 7 and 13) at the district-month level. The first column in Panel B consists of all districts that randomly assigned cases (22 districts). The second column consists of the 84 districts for which we have docket data. All regressions include district and month fixed effects. The table reports ordinary wild bootstrap $p$-values in parentheses.

Panel A

\begin{tabular}{lcc}
\hline & $\begin{array}{c}\text { Female } \\
(1)\end{array}$ & $\begin{array}{c}\text { Age } \\
(2)\end{array}$ \\
\hline Cramdown & 0.0220 & -0.930 \\
& $(0.4384)$ & $(0.2132)$ \\
District FE & $\mathrm{Y}$ & $\mathrm{Y}$ \\
Month FE & $\mathrm{Y}$ & $\mathrm{Y}$ \\
Observations & 14,517 & 14,517 \\
$R$-squared & 0.019 & 0.030 \\
\hline \multicolumn{3}{c}{} \\
Panel B & \multicolumn{2}{c}{} \\
\hline \multicolumn{2}{c}{ Chapter } & 7 share \\
& $(1)$ & $(2)$ \\
Cramdown & -0.0308 & -0.0258 \\
& $(0.6396)$ & $(0.3423)$ \\
District & $\mathrm{Y}$ & $\mathrm{Y}$ \\
Month & $\mathrm{Y}$ & $\mathrm{Y}$ \\
Observations & 2,031 & 6,365 \\
$R$-squared & 0.019 & 0.030 \\
\hline
\end{tabular}

